Vol. 24, No. 1, Januari 2021, hlm. 89-98

\title{
Upaya Pembentukan Desa Safety Farming Melalui Pendekatan Pembelajaran dan Pemberdayaan Masyarakat
}

\author{
${ }^{1}$ Eka Rosanti, ${ }^{2}$ Ratih Andhika Akbar Rahma, ${ }^{3}$ Mahmudah Hamawi \\ 1,2,3 Universitas Darussalam Gontor \\ Email: 11ekarosanti@unida.gontor.ac.id, 2ratihandhika@unida.gontor.ac.id, \\ ${ }^{3}$ mahmudahhamawi@unida.gontor.ac.id
}

\section{Article Info}

Submitted: 19 September 2020

Revised: 21 October 2020

Accepted: 30 October 2020

Published: 12 December 2020

Keywords: safety farming, pesticide, socialization, learning, community development

Kata Kunci : safety farming, pestisida, sosialisasi, pembelajaran, pemberdayaan masyarakat

\section{Abstract}

People in Demangan Village, Siman, Ponorogo, who mostly work as rice farmers and horticulture, often use inorganic pesticides in farming. The unsafe pesticide management can effact to the blood contamination. Therefore, it is necessary to have a learning approach and community empowerment that aims to form a safety farming village as an effort to improve community health status. The method used blood tests, FGD, socialization, and evaluation. The results obtained were that the examining pesticides in the farmers' blood increase the enthusiasm of Gapoktan members towards the dangers of pesticides, the FGD learning approach, and socialization of the dangers of pesticides was able to increase knowledge by $17 \%$ while FGD and socialization about pesticide safety management were able to increase knowledge by 5\%, Gapoktan and Pos UKK were active in all activities. The formation of a safety farming village needs to get support and supervision from health workers and the Agriculture Office. The key to preventing farmer's pesticide contamination is pesticide safety management including the use of PPE and personal hygiene efforts.

Abstrak
Masyarakat di desa Demangan, Siman, Ponorogo, yang kebanyakan
berprofesi sebagai petani padi dan holtikultura sering menggunakan
pestisida anorganik dalam bertani. Penatalaksanaan pestisida yang
kurang aman dapat menyebabkan kontaminasi pestisida dalam
darah. Oleh karena itu, perlu adanya upaya pendekatan pembelajaran
dan pemberdayaan masyarakat yang bertujuan untuk membentuk
desa safety farming sebagai guna meningkatkan tingkat kesehatan
masyarakat. Kegiatan ini menggunakan metode pemeriksaan darah,
FGD, sosialisasi, dan evaluasi. Hasil yang diperoleh adalah hasil
pemeriksaan pestisida dalam darah petani mampu meningkatkan
antusiasme anggota Gapoktan terhadap bahaya pestisida, upaya
pendekatan pembelajaran, FGD, dan sosialisasi bahaya pesitisida


mampu meningkatkan pengetahuan sebesar 17\%, sedangkan FGD dan sosialisasi tentang penatalaksanaan pestisida yang aman dan sehat mampu meningkatkan pengetahuan sebesar 5\%, Gapoktan dan Pos UKK terlibat aktif dalam seluruh kegiatan. Pembentukan desa safety farming perlu mendapatkan dukungan berupa pendampingan dan pengawasan dari petugas kesehatan serta Dinas Pertanian. Kunci keberhasilan upaya pencegahan kontaminasi pestisida terhadap tubuh petani adalah penatalaksanaan pestisida yang aman dan sehat termasuk penggunaan APD dan upaya personal hygiene.

\section{PENDAHULUAN}

Desa Demangan, Kecamatan Siman, Kabupaten Ponorogo, Jawa Timur, memiliki potensi Sumber Daya Alam (SDA) dan Sumber Daya Manusia (SDM) yang saat ini belum dilakukan pemberdayaan secara optimal. Jika dilihat dari hasil panen diketahui bahwa kedelai memiliki tingkat produksi paling tinggi yaitu 1.433 ton, diikuti dengan padi mencapai 800ton setiap sekali musim tanam, jagung sebesar 726 ton, dan ubi kayu sebesar 249 ton (Badan Pusat Statistik Kabupaten Ponorogo, 2018). Selain itu petani juga menanam tanaman hortikultura lain seperti sayur dan buah-buahan.

Petani di Desa Demangan belum menerapkan aspek safety farming (keselamatan dan kesehatan kerja) dalam kegiatan bertani. Safety Farming adalah upaya melakukan kegiatan pertanian sesuai dengan aspek keselamatan (safety) dan kesehatan (health) yang dalam rangka mencegah terjadinya kecelakaan kerja dan penyakitakibat kerja. Dalam pelaksanaannya petani yang tergabung dalam Gabungan

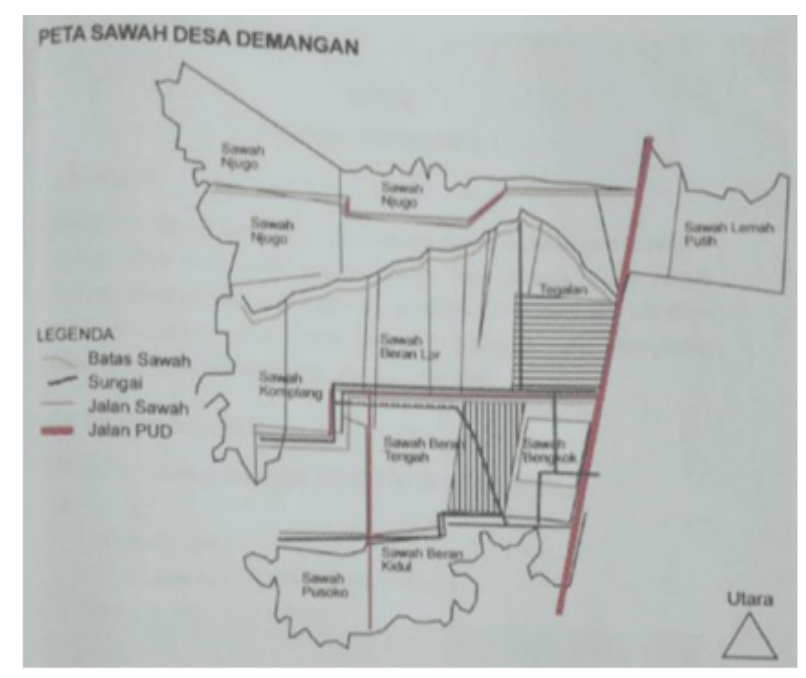

Gambar 1. Peta Sawah Desa Demangan
Kelompok Tani (Gapoktan) akan bersinergi dengan Pos Upaya Kesehatan Kerja (UKK) Desa. Pos UKK memiliki fungsi pelaksanaan pelayanan kesehatan dan keselamatan kerja untuk masyarakat petani. Sehingga mampu melakukan monitoring terhadap keselamatan bekerja dan kesehatan petani. Rendahnya aspek Safety Farming pada petani di Desa Demangan tercermin dalam upaya mengendalikan hama, petani menggunakan pestisida anorganik untuk semua jenis tanaman sesuai gambar 2 .

Tingginya aktivitas penyemprotan tanaman terutama pada kedelai yaitu 5 kali selama satu musim atau setiap 2-3 minggu sekali dapat menimbulkan dampak negatif terhadap kesehatan petani yaitu dapat menghambat kadar enzim kolinesterase dalam darah. Menurut Rijal et al., (2018), hal tersebut dapat mengakibatkan terjadinya kanker, kelahiran cacat, ganggun hormon, gangguan reproduksi, gastrointestinal, dermatological, dan rusaknya sistem nervous. Berdasarkan hasil wawancara dengan petani, sebagian besar petani merasakan pusing dan mual setelah melakukan pencampuran dan penyemprotan pestisida.

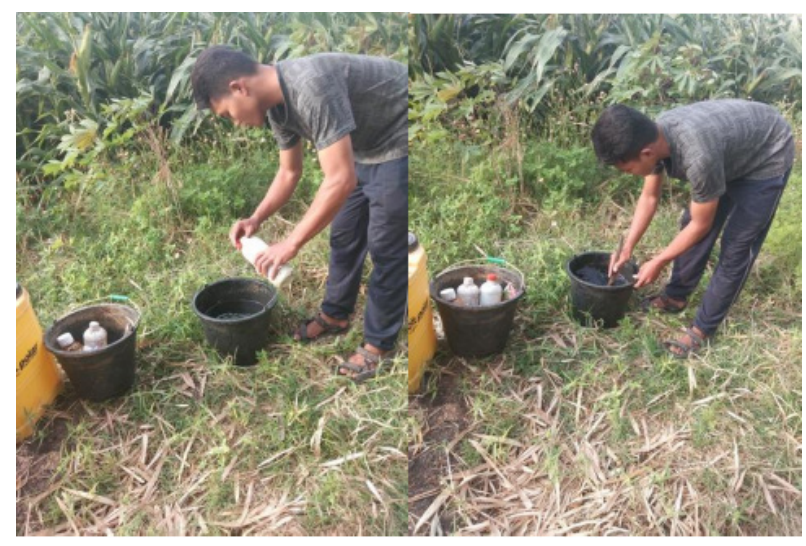

Gambar 2. Kegiatan Mencampur Pestisida Tanpa Menggunakan APD 


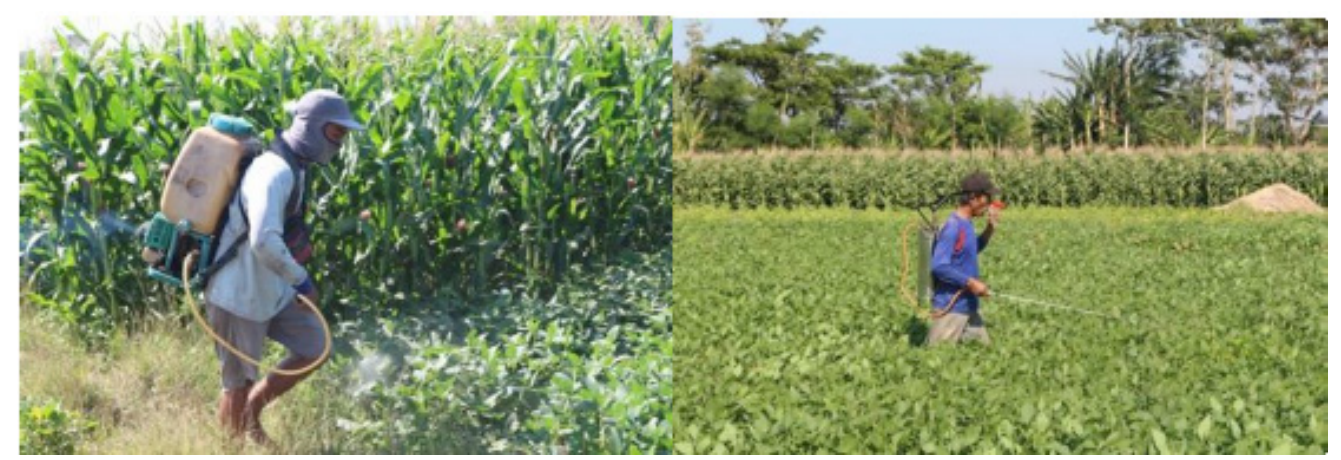

Gambar 3. Kegiatan Menyemprot Pestisida Tanpa Menggunakan APD

Berdasarkan gambar 3 di atas, petani juga tidak menggunakan alat pelindung diri ketika menggunakan pestisida baik ketika menyemprot. Fungsi dari alat pelindung diri yaitu mengisolasi sebagian atau seluruh tubuh dari potensi bahaya di tempat kerja (Rahma, 2018). Petani hanya menggunakan baju yang diikatkan pada mulut dan hidung serta baju panjang. Hal ini dapat meningkatkan keracunan pestisida pada tubuh melalui kulit dan pernafasan. Alat pelindung diri menjadi salah satu faktor penentu risiko keracunan pestisida dalam darah (Damalas \& Eleftherohorinos, 2011).

Data menunjukkan bahwa petani di Desa Demangan sebanyak $60 \%$ berisiko tinggi terhadap keracunan pestisida (Andarini \& Rosanti, 2018). Setelah dilakukan observasi diperoleh data bahwa personal hygiene petani masih buruk, diantaranya tidak mencuci tangan dengan sabun setelah beraktivitas, bahkan mereka mencuci tangan menggunakan air sawah yang tidak bersih dan tentunya telah tercampur dengan pestisida. Petani tidak segera mandi setelah melakukan penyemprotan serta tidak memisahkan pencucian baju bertani dengan baju anggota keluarga lainnya. Hal ini dapat meningkatkan keracunan pestisida pada tubuh melalui kulit dan oral.

Sebagian besar petani di Desa Demangan beraktivitas sebagai petani sejak remaja bahkan ketika masa anak-anak. Sehingga aktivitas pertanian dilakukan secara turun temurun yang berdampak pada penatalaksanaan pestisida berdasarkan kepercayaan dan pengalaman. Meskipun penyuluh pertanian telah memberikan informasi kepada sebagian petani tentang penatalaksanaan pestisida yang aman dan sehat, akan tetapi petani lebih menganut kebiasaannya.
Tim pengabdian telah membentuk Pos Upaya Kesehatan Kerja (UKK) Demang Jaya Sehat di Desa Demangan pada Tahun 2016 yang berfungsi mengawasi dan meningkatkan derajat kesehatan petani melalui program kerjanya. Namun karena kurangnya pendampingan dari petugas kesehatan dan kesibukan kader yang juga sebagai petani, maka Pos UKK tersebut belum beroperasional dengan baik.

Berdasarkan permasalahan tersebut, maka tim melakukan pengabdian kepada masyarakat untuk membentuk Desa Safety Farming, khususnya petani di Desa Demangan yang tergabung dalam Gapoktan Demang Jaya. Pembentukan Desa Safety Farming memiliki beberapa keunggulan yaitu dapat membangun kesadaran petani untuk dapat berperilaku aman dan sehat ketika bertani. Adanya Pos UKK dalam pembentukan Desa Safety Farming ini dapat me-monitoring kesehatan petani secara berkala. Agar Desa Safety Farming dapat berjalan maka perlu kelengkapan Sarana dan Prasarana berupa Rumah Simpan dan Bilas Pestisida yang dilengkapi dengan APD (katelpak, kacamata, respirator, sarung tangan karet, apron, sepatu boot), box penyimpanan pestisida, Alat Pemadam Api Ringan (APAR), dan kotak P3K. Rumah simpan dan bilas pestisida juga dilengkapi dengan tempat untuk mandi. Pengabdian ini difokuskan pada upaya mencegah dan mengendalikan keracunan pestisida pada tubuh petani sejak membeli, mencampur, membawa, menyemprot dan penatalaksanaan botol bekas pestisida.

\section{METODE}

Kegiatan pengabdian kepada masyarakat dilakukan dalam bentuk pemeriksaan kadar 
pestisida dalam darah, Focus Group Discussion (FGD), dan sosialisasi. Kegiatan ini dilaksanakan pada bulan Juni sampai dengan Agustus 2020 yang melibatkan dua mitra yaitu Gabungan Kelompok Tani (Gapoktan) Demang Jaya dan Kader Pos UKK Demang Jaya Sehat di Desa Demangan, Kecamatan Siman, Kabupaten Ponorogo.

Kegiatan pengabdian kepada masyarakat ini bertujuan untuk membentuk desa safety farming menggunakan pendekatan pembelajaran dan upaya pemberdayaan masyarakat. Tim pengabdian bekerja sama dengan laboratorium Prodia Madiun untuk pengambilan sampel darah. Setelah hasil pemeriksaan keluar, tim mengajak anggota Gapoktan dan kader untuk berdiskusi. Kegiatan dilanjutkan dengan sosialisasi bahaya pestisida pada kesehatan.

Adapun tahapan kegiatan pengabdian seperti pada gambar 4 .

Berdasarkan gambar 4, kegiatan pengabdian diawali melalui koordinasi dengan pihak terkait yaitu mitra, prodia, dan nara sumber. Selanjutnya untuk memberikan gambaran tentang kondisi terkini kesehatan petani, tim pengabdian melakukan pemeriksaan kolinesterase untuk mengetahui kadar pestisida dalam darah. Hal ini dimaksudkan agar petani semakin sadar akan bahaya pestisida bagi kesehatan. Pada FGD hasil pemeriksaan kadar pestisida dalam tubuh, petani aktif berdiskusi dengan tim pengabdian dan nara sumber untuk memperoleh solusi. Pada kesempatan tersebut tim pengabdian menjelaskan pentingnya aspek safety dalam kegiatan bertani. Kegiatan sosialisasi bahaya pestisida terhadap tubuh dan penatalaksanaan pestisida yang aman dan sehat dilakukan untuk menanamkan pengetahuan safety farming kepada petani. Tahapan sosialisasi dimulai dengan pre-test di mana petani menjawab beberapa pertanyaan pada kuesioner untuk mengetahui pengetahuan awal petani sebelum dilakukan sosialisasi. Kegiatan dilanjutkan dengan pemberian materi penyuluhan tentang bahaya pestisida pada kesehatan, pentingnya kebersihan perorangan dan penatalaksanaan pestisida yang aman dan sehat. Kegiatan selanjutnya yaitu diskusi tanya jawab dan diakhiri dengan mengerjakan pertanyaan posttest untuk mengetahui pengetahuan petani setelah kegiatan sosialisasi. Untuk mengetahui efektivitas kegiatan pengabdian maka dilakukan evaluasi yang mencakup aspek peningkatan pengetahuan mitra tentang bahaya pestisida dan penatalaksanaan pestisida yang aman dan sehat,

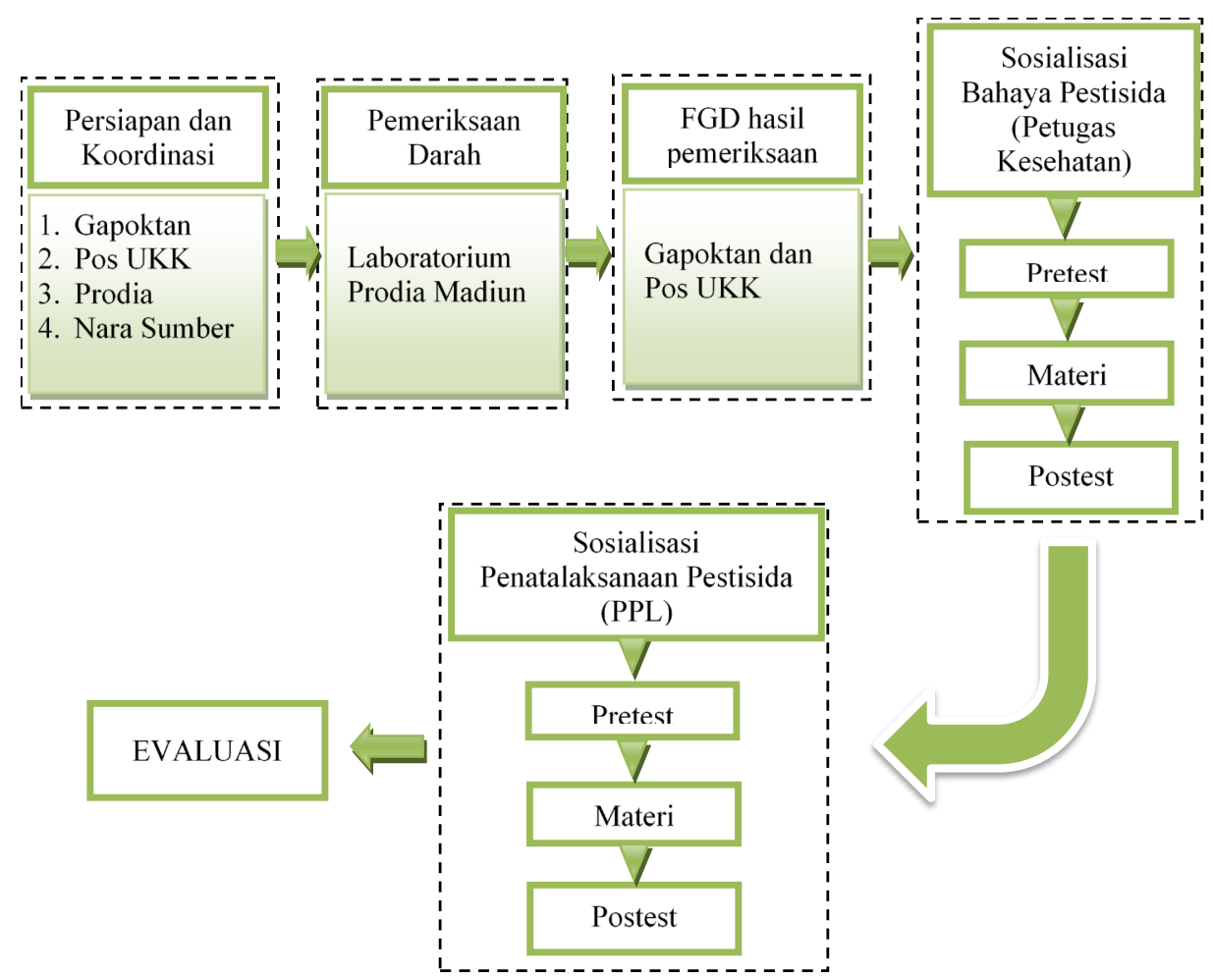

Gambar 4. Diagram Tahapan Kegiatan Pengabdian Kepada Masyarakat 
kesadaran petani untuk menggunakan APD serta pemanfaatan rumah simpan dan bilas pestisida sebagai indikator Desa Safety Farming.

\section{HASIL DAN PEMBAHASAN}

Kegiatan pengabdian kepada masyarakat yang menggunakan pendekatan pembelajaran dan pemberdayaan masyarakat ini selain melibatkan mitra yaitu Gapoktan Demang Jaya dan Pos UKK Demang Jaya Sehat, juga mendapatkan dukungan dari Dinas Kesehatan dan Dinas Pertanian Kabupaten Ponorogo. Selain itu, mahasiswa dari Program Studi Keselamatan dan Kesehatan Kerja serta Agroteknologi juga turut menjadi pembantu pelaksana kegiatan.

Berikut ini adalah uraian tahapan kegiatan pengabdian kepada masyarakat:

\section{a. Persiapan dan Koordinasi}

Pada tahap persiapan, tim pengabdian membuat jadwal yang terstruktur dan sistematis berdasarkan usulan yang telah disetujui oleh Kementerian Riset dan Teknologi BRIN Tahun 2020. Hal-hal yang perlu dipertimbangkan untuk persiapan dilihat dari aspek sumber daya manusia (mitra, stakeholder, laboratorium klinik, tim pengabdian termasuk mahasiswa), finansial, dan sarana serta prasarana.

Kegiatan selanjutnya yaitu melakukan koordinasi dengan pihak terkait yaitu:

1. Tim Pengabdian

Kegiatan koordinasi dilakukan pada awal, setiap kegiatan, monitoring, dan evaluasi. Kegiatan dilakukan untuk selalu menjaga persamaan visi dari tim serta agar kegiatan berjalan sesuai rencana yang telah tertuang pada jadwal.

2. Mitra 1

Mitra 1 yaitu Gapoktan Demang Jaya Desa Demangan yang terdiri dari 5 kelompok tani. Dalam setiap koordinasi kegiatan, tim pengabdian selalu berkoordinasi dengan ketua Gapoktan dan ketua masing-masing kelompok tani. Melalui cara ini, ketua kelompok tani mampu menjadi penggerak bagi anggotanya.

3. Mitra 2

Mitra 2 yaitu Pos UKK Demang Jaya Sehat yang terdiri dari ketua dan kader. Dalam setiap koordinasi kegiatan, tim pengabdian juga selalu melibatkan kader Pos UKK secara aktif. Kegiatan Pos UKK dan kelompok tani bersifat sinergis. Diharapkan setelah kegiatan pengabdian, Pos UKK mampu mengawasi pelaksanaan pertanian yang aman dan sehat (Direktorat Jenderal Bina Gizi dan Kesehatan Ibu dan Anak, 2011).

4. Dinas Kesehatan

Salah satu pihak yang memiliki peran penting dalam program desa safety farming ini adalah Dinas Kesehatan Kabupaten Ponorogo. Melalui bidang Kesehatan Masyarakat, tim pengabdian melakukan koordinasi untuk kegiatan pemeriksan darah serta FGD, sosialisasi bahaya pestisida dan personal hygiene.

5. Dinas Pertanian

Pihak selanjutnya yang juga memiliki peran penting adalah Dinas Pertanian Kabupaten Ponorogo melalui Petugas Penyuluh Lapangan (PPL). Tim PPL mendampingi dalam kegiatan sosialisasi penatalaksanaan pestisida yang aman dan sehat.

6. Laboratorium Klinik

Tim pengabdian bekerjasama dengan laboratorium Prodia Madiun dalam pengambilan sampel darah (kadar kolinesterase) untuk mengetahui keracunan pestisida dalam tubuh petani.

\section{b. Pemeriksaan Darah}

Kegiatan pemeriksaan dengan mengambil sampel darah petani seperti pada gambar 5 dilakukan oleh laboratorium Prodia Madiun pada tanggal 26 Juni 2020 di Balai Desa Demangan dan di sawah salah satu petani. Dinas Kesehatan dan Tim PPL Dinas Ponorogo juga turut hadir untuk mendukung kelancaran kegiatan. Kegiatan ini bertujuan untuk mengetahui kadar pestisida dalam darah petani menggunakan indikator kadar enzim kolinesterase. Menurut Lionetto et al., (2013) dan Hu et al., (2015) pestisida yang masuk ke dalam tubuh bersifat menghambat enzim kolinesterase. Asare, (2015), Rijal et al., (2018), dan Kapeleka et al., (2019) menyatakan bahwa hal tersebut dapat menyebabkan terjadinya berbagai penyakit akibat gangguan hormon dan nervous system yang bermanifestasi terhadap kanker serta kematian. 


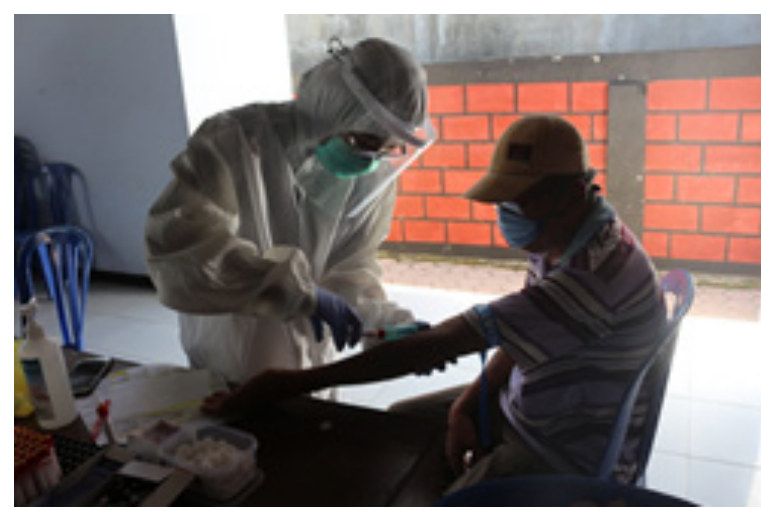

Gambar 5. Kegiatan Pemeriksaan Kadar Pestisida dalam darah oleh Prodia

Terdapat 57 petani yang mengikuti kegiatan pemeriksaan darah, terdiri dari petani padi dan hortikultura. Petani yang terlibat adalah anggota Gapoktan Demang Jaya, aktif menggunakan pestisida anorganik dan bersifat sukarela. Dalam kegiatan ini, Pos UKK Demang Jaya Sehat juga melakukan pemeriksaan kesehatan umum kepada petani yang terdiri dari tes kolesterol, asam urat dan gula darah. Adapun hasil pemeriksaan kadar pestisida dalam darah menyatakan bahwa seluruh petani berada pada rentang normal yaitu 5,320-12,920, namun terdapat beberapa penjelasan risiko.

Hasil pemeriksaan kadar pestisida dalam darah (dapat dilihat pada tabel 1) disampaikan secara individu kepada petani dan dibahas pada kegiatan FGD. Melalui kegiatan ini petani memperoleh pengetahuan terkait pemeriksaan kadar pestisida dalam darah. Kegiatan yang dilakukan dengan pendekatan pembelajaran ini bertujuan untuk memperoleh data awal dan bahan untuk kegiatan FGD yang dilanjutkan dengan sosialisasi.

\section{c. FGD Hasil Pemeriksaan}

Hasil pemeriksaan di atas disampaikan pada kegiatan arisan bulanan anggota Gapoktan

Tabel 1. Hasil Pemeriksaan Kadar Pestisida dalam Darah

\begin{tabular}{clcc}
\hline No. & $\begin{array}{c}\text { Kategori Kadar } \\
\text { Pestisida }\end{array}$ & Jumlah & Persentase \\
\hline 1. & Berisiko Sangat Tinggi & 6 & 10,53 \\
\hline 2. & Berisiko Tinggi & 17 & 29,82 \\
\hline 3. & Berisiko Sedang & 26 & 45,61 \\
\hline 4. & Berisiko Rendah & 8 & 14,04 \\
\hline
\end{tabular}

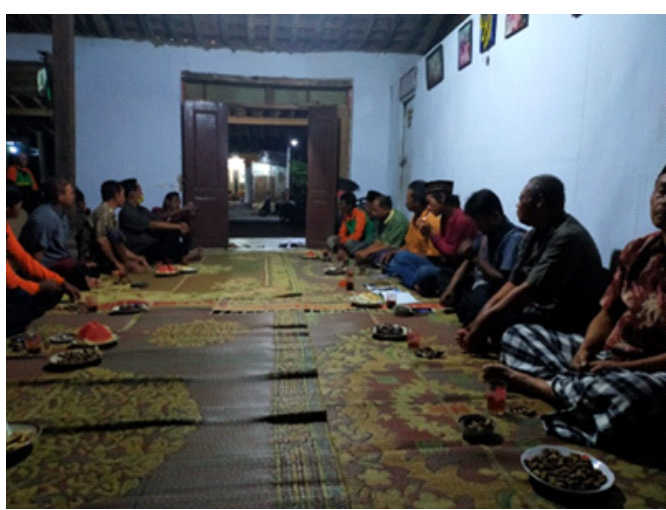

Gambar 6. FGD Hasil Pemeriksaan Kadar

Pestisida dalam Darah di Salah Satu Rumah Warga

Demang Jaya yaitu tanggal 14 Juli 2020 di salah satu rumah warga seperti pada gambar 6. Kader Pos UKK Demang Jaya Sehat juga turut hadir dalam kegiatan tersebut sekaligus terlibat dalam panitia bersama Gapoktan. Kepanitiaan kegiatan yang selalu melibatkan mitra dilakukan sebagai upaya pemberdayaan masyarakat melalui kultur budaya sehingga mampu meningkatkan keberhasilan program. Setelah seluruh petani memperoleh hasil pemeriksaan masing-masing, tim pengabdian menjelaskan makna dari hasil tersebut.

Selain menjelaskan kategori normal dan tidak normal, tim pengabdian juga menjelaskan nilai yang berisiko tinggi terhadap keracunan pestisida dalam darah. Petani dan kader sangat aktif berdiskusi dengan tim pengabdian. Sebagian besar menanyakan solusi untuk petani yang berada pada kategori tidak normal dan berisiko tinggi. Tim pengabdian menjelaskan bahwa perilaku petani dalam menggunakan pestisida menjadi kunci penting dalam mencegah kontaminasi atau keracunan pestisida dalam darah (Elvis Asare, 2015). Oleh karena itu, tim menghimbau kepada petani yang berada pada kategori tidak normal dan berisiko tinggi untuk beristirahat $2-4$ minggu dari kegiatan menyemprot dan mulai berperilaku aman dan sehat. Dalam kegiatan FGD ini, petani setuju untuk memperoleh pengetahuan tentang bahaya pestisida ke dalam tubuh.

\section{d. Sosialisasi Bahaya Pestisida}

Kegiatan pengabdian yang berkelanjutan ini diteruskan dengan sosialisasi bahaya pestisida dan upaya personal hygiene yang dilaksanakan 
pada tanggal 10 Agustus 2020 di Balai Desa Demangan seperti pada gambar 7. Narasumber berasal dari Bidang Kesehatan Masyarakat Dinas Kesehatan Kabupaten Ponorogo. Kegiatan diawali dengan pretest, kemudian dilanjutkan dengan materi serta diskusi, tanya jawab, dan diakhiri dengan posttest. Materi yang disampaikan meliputi:

1. Pengertian pestisida

2. Cara masuk pestisida ke dalam tubuh

3. Dampak penggunaan pestisida terhadap kesehatan

4. Permasalahan praktik penggunaan pestisida pada kebiasaan petani

5. Personal hygiene petani pada saat menggunakan pestisida

Petani sangat tertarik dengan materi yang disampaikan, karena narasumber memaparkan materi secara visual disertai gambar. Sehingga petani mudah memahami dan menangkap maksud dari materi tersebut. Pada sosialisasi ini, petani juga menanyakan upaya yang harus dilakukan agar kadar pestisida dalam darah tetap normal. Narasumber pun menyatakan bahwa hal itu dapat dilakukan dengan mengkonsumsi makanan yang banyak mengandung antioksidan dan vitamin. Vitamin C dan selenium dapat meningkatkan kadar CheA pada petani yang keracunan pestisida (Anggraini \& Pratiwi, 2018). Selain itu petani juga dihimbau untuk banyak minum air putih agar pestisida dapat keluar melalui keringat dan air seni (Direktorat Jenderal Kesehatan Masyarakat, 2016).

Hasil pretest dan posttest petani tentang bahaya pestisida terhadap tubuh dapat dilihat pada gambar 8 .

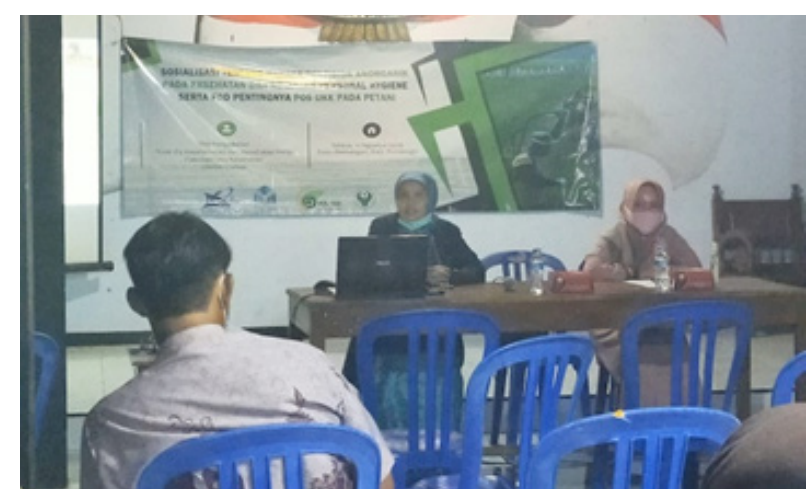

Gambar 7. Sosialisasi oleh Petugas Dinas Kesehatan Kabupaten Ponorogo

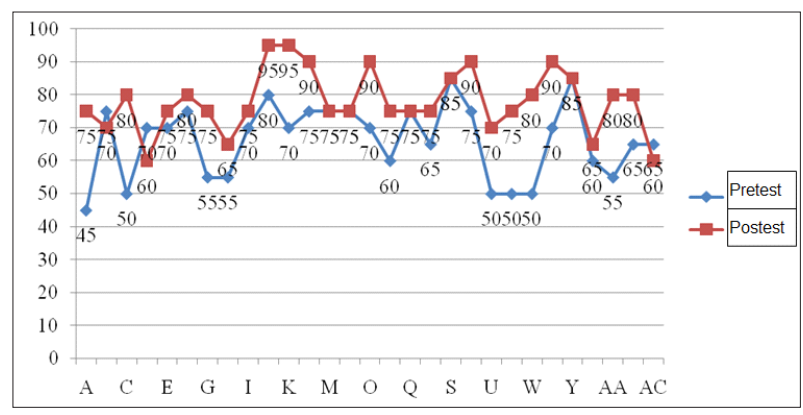

Gambar 8. Perbandingan Hasil Pretest dan

Posttest Petani pada Kegiatan Sosialisasi Bahaya Pestisida

Dari gambar 8 diketahui bahwa terdapat rata-rata peningkatan pengetahuan bahaya pestisida dan personal hygiene pada petani dari rata-rata nilai 66,2 menjadi 77,9 atau meningkat sebesar $17 \%$. Hal ini membuktikan bahwa kegiatan sosialisasi dapat meningkatkan pemahaman dan pengetahuan petani. Sehingga dengan bekal pengetahuan yang baik diharapkan mampu meningkatkan perilaku aman dan sehat dalam menggunakan pestisida (Damalas \& Koutroubas, 2017).

\section{e. Sosialisasi Penatalaksanaan Pestisida yang Aman dan Sehat}

Penanaman pengetahuan melalui sosialisasi perlu diimbangi dengan praktik penatalaksanaan pestisida dan botol bekas pestisida yang aman dan sehat mulai dari membeli, mencampur, membawa dan menyemprot. Kegiatan yang melibatkan mitra (Gapoktan dan Pos UKK) serta Petugas PPL Dinas Pertanian Kabupaten Ponorogo sebagai narasumber dilaksanakan pada tanggal 19 Agustus 2020 di area sawah Desa Demangan. Kegiatan diawali dengan pretest kemudian materi diikuti diskusi, tanya jawab, dan diakhiri dengan posttest.

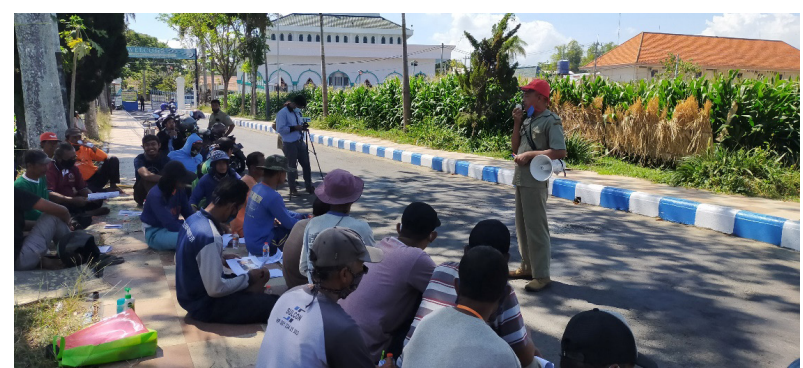

Gambar 9. Sosialisasi oleh Petugas PPL Dinas Pertanian Kabupaten Ponorogo 
Berdasarkan gambar 9, narasumber menayangkan contoh perilaku sehari-hari petani yang tidak aman dalam menggunakan pestisida. Sehingga petani tertarik hingga mengakui hal tersebut. Berikut ini adalah materi yang disampaikan oleh narasumber:

1. Membaca label produk pestisida dengan benar.

2. Menyimpan pestisida di lahan/sawah dengan benar.

3. Menangani sprayer yang tersumbat dengan benar.

4. Penjelasan upaya mencampur pestisida yang berbahaya untuk kesehatan.

5. Efek additive dan sinergis bahan kimia yang terkandung dalam pestisida.

6. Cara melakukan pencampuran dan penyemprotan pestisida dengan benar, aman dan sehat.

7. Alat pelindung diri sebagai upaya mencegah kontaminasi pestisida pada tubuh petani.

8. Cara melakukan penatalaksanaan botol sisa pestisida dengan benar dan aman.

Petani berdiskusi aktif dengan narasumber, hal yang paling membuat petani tertarik adalah pada poin penggunaan Alat Pelindung Diri (APD) yang selama ini masih awam bagi petani karena memerlukan biaya untuk pengadaannya. Selain itu juga terkait pencampuran 2 pestisida atau lebih yang dapat membahayakan kesehatan. Petani sering tidak membaca bahan yang terkandung dalam pestisida, karena terdapat kemungkinan berefek additive dan sinergis (Wilson \& Tisdell, 2001).

Tim pengabdian menjelaskan bahwa akan menyediakan APD untuk masing-masing kelompok tani yang terdiri dari:

1. Katelpak (Baju Pelindung Pestisida)

2. Face Shield (Tameng)

3. Goggles (Kacamata)

4. Respirator

5. Sarung Tangan

6. Sepatu Boot

7. Apron (Celemek)

APD menjadi salah satu faktor yang efektif dalam mencegah kontaminasi pestisida pada tubuh petani. Selain itu petugas PPL menambahkan bahwa pencampuran 2 bahan pestisida atau lebih dapat mengakibatkan resistensi terhadap hama tanaman (Putter et al., 2017). Hasil pretest dan postest petani tentang penatalaksanaan pestisida yang aman dan sehat seperti pada gambar 10 .

Dari gambar 10 diketahui bahwa terdapat rata-rata peningkatan pengetahuan penatalaksanaan pestisida yang aman dan sehat pada petani sebesar 5\%. Hal ini membuktikan bahwa kegiatan sosialisasi yang diiringi dengan praktik dapat meningkatkan pengetahuan serta keterampilan petani (Damalas \& Koutroubas, 2017).

\section{f. Evaluasi}

Evaluasi dilakukan untuk menilai ketercapaian program serta hambatan yang dihadapi. Setelah melalui seluruh tahapan diperoleh hasil evaluasi bahwa kegiatan pemeriksaan kadar pestisida dalam darah mampu meningkatkan kesadaran petani akan bahaya pestisida. Hal ini terlihat dari antusias petani ketika mengikuti FGD dan pembangunan rumah simpan dan bilas pestisida secara swadaya. Selain itu kegiatan sosialisasi mampu meningkatkan pengetahuan petani tentang bahaya pestisida terhadap tubuh dan penatalaksanaan pestisida yang aman dan sehat. Perlu melakukan pengadaan APD sebagai sarana mencegah kontaminasi pestisida dalam tubuh, sehingga peran petugas kesehatan sangat penting dalam pendampingan serta pengawasan. Kader masih perlu meningkatkan keterampilan melalui pendampingan khusus dari petugas kesehatan karena sudah lama tidak beroperasional.

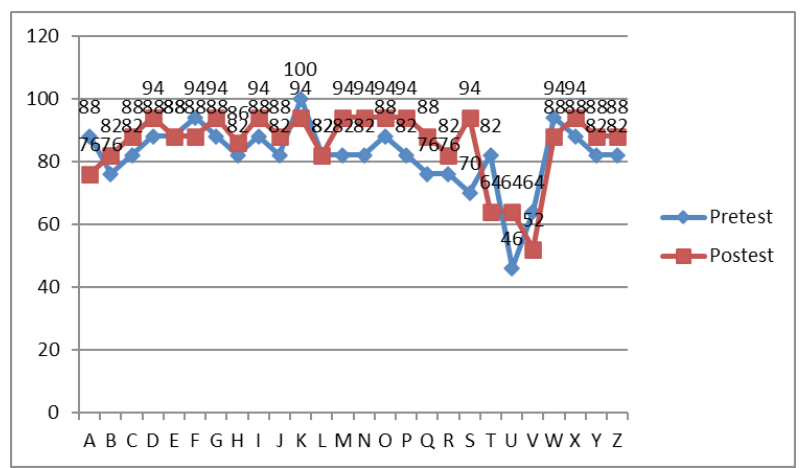

Gambar 10. Perbandingan Hasil Pretest dan Posttest Petani pada Kegiatan Sosialisasi Penatalaksanaan Pestisida yang Aman dan Sehat 


\section{SIMPULAN}

Berdasarkan pelaksanaan kegiatan diperoleh simpulan bahwa kegiatan pembelajaran melalui sosialisasi, FGD, dan praktik penatalaksanaan pestisida mampu meningkatkan pengetahuan dan kesadaran petani tentang safety farming. Desa Safety Farming ini dapat terwujud dengan adanya antusias dan partisipasi aktif dari masyarakat baik Gapoktan maupun Pos UKK. Poin penting dari pembentukan Desa Safety Farming adalah pemberdayaan masyarakat yaitu dari dan untuk masyarakat. Upaya pemberdayaan juga diwujudkan melalui pemanfaatan kultur budaya dan gotong royong yang ada di masyarakat, yaitu memasukkan pembahasan hasil pemeriksaan FGD pada arisan bulanan Gapoktan Demang Jaya.

\section{UCAPAN TERIMA KASIH}

Terima kasih kami haturkan kepada Kemenristek/BRIN yang telah mendanai kegiatan Pengabdian ini pada skim Program Pemberdayaan Desa Mitra (PPDM) Tahun 2020 serta Gapoktan Demang Jaya dan Pos UKK Demang Jaya Sehat sebagai mitra dalam kegiatan ini. Ucapan terima kasih juga disampaikan atas dukungan dari LPPM Universitas Darussalam Gontor, Jajaran Rektor Universitas Darussalam Gontor, Dinas Kesehatan, dan Dinas Pertanian Kabupaten Ponorogo.

\section{DAFTAR PUSTAKA}

Andarini, Y. D., \& Rosanti, E. (2018). Kajian Toksisitas Pestisida Berdasarkan Masa Kerja dan Personal Hygiene pada Petani Hortikultura di Desa Demangan. An-Nadaa: Jurnal Kesehatan Masyarakat, 5(2), 82. https://doi.org/10.31602/ann.v5i2.1655

Anggraini, D. I., \& Pratiwi, A. (2018). Vitamin C dan Selenium (Se): Pencegah Keracunan Pestisida. Journal Agromedicine, 5(1), 503-507. http://juke.kedokteran.unila.ac.id/index.php/agro/ article/download/1992/pdf

Badan Pusat Statistik Kabupaten Ponorogo. (2018). Kabupaten Ponorogo dalam Angka 2018. In BPS Kabupaten Ponorogo.

Damalas, C. A., \& Eleftherohorinos, I. G. (2011). Pesticide Exposure, Safety Issues, and Risk Assessment Indicators. International Journal of Environmental Research and Public Health, 8(5), 1402-1419. https://doi.org/10.3390/ijerph8051402

Damalas, C. A., \& Koutroubas, S. D. (2017). Farmers' Training on Pesticide Use is Associated with Elevated Safety Behavior. Toxics, 5(3). https://doi.org/10.3390/toxics5030019

Direktorat Jenderal Bina Gizi dan Kesehatan Ibu dan Anak. (2011). Pedoman Penyelenggaraan Upaya Kesehatan Kerja (UKK) untuk Kadek Pos UKK. Kementerian Kesehatan RI. https://kink.onesearch. id/Record/IOS2902.YOGYA000000000001890

Direktorat Jenderal Kesehatan Masyarakat. (2016). Pedoman Penggunaan Pestisida Aman dan Sehat di Tempat Kerja Sektor Pertanian (Issue November 2016).

Elvis Asare, V. A. S. (2015). Pesticide Use Practices and Perceptions of Vegetable Farmers in the Cocoa Belts of the Ashanti and Western Regions of Ghana. Advances in Crop Science and Technology, 03(03). https://doi.org/10.4172/2329-8863.1000174

Hu, R., Huang, X., Huang, J., Li, Y., Zhang, C., Yin, Y., Chen, Z., Jin, Y., Cai, J., \& Cui, F. (2015). Long- and ShortTerm Health Effects of Pesticide Exposure: A Cohort Study from China. PLoS ONE, 10(6), 1-13. https://doi.org/10.1371/journal.pone.0128766

Kapeleka, J. A., Sauli, E., Sadik, O., \& Ndakidemi, P. A. (2019). Biomonitoring of Acetylcholinesterase (AChE) Activity among Smallholder Horticultural Farmers Occupationally Exposed to Mixtures of Pesticides in Tanzania. Journal of Environmental and Public Health, 2019. https://doi. org/10.1155/2019/3084501 
Rosanti, dkk - Upaya Pembentukan Desa Safety Farming ...

Lionetto, M. G., Caricato, R., Calisi, A., Giordano, M. E., \& Schettino, T. (2013). Acetylcholinesterase as A Biomarker in Environmental and Occupational Medicine: New Insights and Future Perspectives. BioMed Research International, 2013. https://doi.org/10.1155/2013/321213

Putter, H. De, Adiyoga, W., \& Sugiharto, J. (2017). Effect of Pesticide Mixing on Control of Anthracnose and Spodoptera exigua in Shallot.

Rahma, R. (2018). Khadimul ummah. Khadimul Ummah: Journal of Social Dedication, 1(2), 93-101. https://ejournal.unida.gontor.ac.id/index.php/khadimulummah/article/view/2493/1512

Rijal, J. P., Regmi, R., Ghimire, R., Puri, K. D., Gyawaly, S., \& Poudel, S. (2018). Farmers' Knowledge on Pesticide Safety and Pest Management Practices: A Case Study of Vegetable Growers in Chitwan, Nepal. Agriculture (Switzerland), 8(1). https://doi.org/10.3390/agriculture8010016

Wilson, C., \& Tisdell, C. (2001). Why Farmers Continue to Use Pesticides Despite Environmental, Health and Sustainability Costs. Ecological Economics, 39(3), 449-462. https://doi.org/10.1016/S09218009(01)00238-5 
Vol. 24, No. 1, Januari 2021, hlm. 99-111

p-ISSN: 1410-9344; e-ISSN: 2549-5631

WARTA LPM

homepage: http://journals.ums.ac.id/index.php/warta

\title{
Penataan Visual Signage Koridor Jalan Bunga Ejaya Kelurahan Bontoala Tua Kecamatan Bontoala Kota Makassar
}

\author{
Citra Amalia Amal ${ }^{1}$, Andi Annisa Amalia ${ }^{2}$ \\ Prodi Arsitektur Universitas Muhammadiyah Makassar \\ Email: ${ }^{1}$ citraamaliaamal@unismuh.ac.id, 2annisa@unismuh.ac.id
}

\begin{tabular}{l} 
Article Info \\
\hline \multicolumn{1}{c}{ Submitted: 11 May 2020} \\
Revised: 6 July 2020 \\
Accepted: 16 November 2020 \\
Published: 12 December 2020 \\
Keywords : Corridor nodes, \\
Identity, Signage, Arabic \\
Cemeteries, Islamic
\end{tabular}

Kata Kunci : Node koridor, Identitas, Signage, Pemakaman Arab, Islami.

\begin{abstract}
Bontoala Tua Village is an old city area of Makassar which marks the development period of Islam in Makassar City. One of the historical evidence of the development of Islam in this place, the Sayye (Arabic) Cemetery Complex, Lajangiru Tomb and Ejaya Flower Tomb located on Jalan Bunga Ejaya. However, the linkage corridor to the place has not been arranged properly, at the connecting corridor node to the location there is no information board or signage making it difficult for visitors or pilgrims because there is no location identity as a marker leading to the burial location. Whereas the nodes and nodes of the lane leading to this place are the linkage connecting the main corridors of the city such as Jalan Veteran and Jalan Masjid Raya Makassar. The purpose of community service activities is to design and create signage of the Arabic Cemetery on Jalan Bunga Ejaya that meets the elements of visibility (visible), legibility (readable) and visual aspects (aesthetic). The method of implementing the activity is participatory approach, ground survey, discussion and design. Stages of activities carried out consisted of socialization, field surveys, discussion of concepts, preparation of tools and materials as well as assembly and installation of the Arab Bontoala Cemetery signage. Signage that is implemented in Jalan Bunga Ejaya Corridor is a type of free standing sign which is a signpost element to the location of the Arab Bontoala Cemetery. This signage has an Islamic concept with a visual display of green, simple, lightweight, simple and the shape of the pillar is integrated with the information board that is placed at the node of Jalan Bunga Ejaya with Jalan Lamuru.
\end{abstract}

Abstrak
Kelurahan Bontoala Tua merupakan kawasan Kota lama Makassar
yang menandai masa perkembangan agama Islam di Kota Makassar.
Salah satu bukti sejarah perkembangan Islam di tempat ini, adanya
Kompleks Pemakaman Sayye (Arab) yaitu Makam Lajangiru dan
Makam Bunga Ejaya yang terletak di Jalan Bunga Ejaya. Namun koridor
linkage menuju tempat tersebut belum tertata dengan baik, pada node


koridor penghubung menuju lokasi tidak terdapat papan informasi atau signage sehingga menyulitkan pengunjung atau peziarah karena belum ada identitas lokasi sebagai penanda menuju ke lokasi pemakaman tersebut. Padahal node dan simpul-simpul jalur menuju tempat tersebut merupakan linkage penghubung koridor utama Kota seperti Jalan Veteran dan Jalan Masjid Raya Makassar. Tujuan kegiatan pengabdian masyarakat adalah mendesain dan membuat signage Pemakaman Arab di Jalan Bunga Ejaya yang memenuhi unsur visibilitas (terlihat), legibilitas (terbaca), dan aspek visual (estetika). Metode yang digunakan dalam kegiatan penataan visual signage ini adalah metode participatory approach (pendekatan semi partisipatif). Tahapan kegiatan yang dilakukan terdiri dari sosialisasi, survei lapangan, diskusi konsep, persiapan alat dan bahan serta perakitan, dan pemasangan signage Pemakaman Arab Bontoala. Signage yang diimplementasikan pada Koridor Jalan Bunga Ejaya adalah jenis free standing sign merupakan elemen penunjuk arah ke lokasi Pemakaman Arab Bontoala. Signage ini berkonsep Islami dengan tampilan visual warna hijau, simpel, ringan, sederhana, dan bentuk tiang menyatu dengan papan informasinya yang ditempatkan pada node Jalan Bunga Ejaya dengan Jalan Lamuru.

\section{PENDAHULUAN}

Kelurahan Bontoala Tua yang terletak di bagian barat pusat Kota Makassar memiliki batas-batas administratif sebagai berikut: di sebelah utara berbatasan dengan Kelurahan Bunga Ejaya, sebelah selatan berbatasan dengan Kelurahan Bontoala, sebelah timur berbatasan dengan Kelurahan Baraya dan sebelah barat berbatasan dengan Kecamatan Bontoala. Luas permukiman adalah 10,59 $\mathrm{Ha}$, secara administrasi terbagi dalam 5 wilayah RW dan 24 RT. Bontoala Tua merupakan kawasan Kota lama Makassar yang menandai perkembangan agama Islam di Kota Makassar. Pada tempat ini terdapat Pemakaman Sayye' (Arab). Adapun Pemakaman tersebut berada pada koridor utama Jalan Bunga Ejaya, titik lokasi dapat dilihat pada Gambar 1.

Masuknya agama Islam penduduk pribumi nusantara serta terbentuknya pemerintahan Islam di berbagai daerah kepulauan termasuk di Sulawesi Selatan. Orang Arab yang bermigrasi ke nusantara juga semakin banyak, yang terbesar diantaranya adalah berasal dari Hadramaut, Yaman. Migrasi ini bahkan terbesar sepanjang Hadramaut. Salah satu bukti adanya kedatangan orang Arab pada masa itu adalah ditemukan makam atau kompleks makam orang Arab yang diketahui oleh masyarakat sekitarnya atau dapat dikenal melalui inskripsi di dalamnya (Zubair, 2011). Disebutkan pula bahwa di Sulawesi Selatan terdapat kompleks makam besar milik penyiar agama Islam ratusan tahun silam yang bangunannya berbentuk kubah masjid dan tempat ini secara turun temurun dikenal dengan kompleks pemakaman orang Arab.

Di Kecamatan Bontoala, Kota Makassar, Provinsi Sulawesi Selatan terdapat sebuah situs berupa kompleks makam yang disebut Makam Lajangiru di mana di tempat tersebut terdapat lima makam besar yang bangunannya berbentuk kubah masjid, mereka yang dimakamkan di tempat tersebut adalah Penyiar Agama Islam ratusan tahun silam. Masyarakat setempat sering menyebut tempat ini sebagai Pemakaman Arab. Keberadaan dan akses menuju Pemakaman Arab di Bontoala Tua tidak mudah diketahui karena secara visual belum ada penanda atau signage menuju ke lokasi tersebut. Padahal umumnya, signage sebagai elemen visual dominan pada suatu koridor dan memiliki peran penting dalam memberikan informasi dan gambaran figure ground yang ada pada suatu tempat.

Koridor Jalan Bunga Ejaya (lihat Gambar 1) merupakan akses utama menuju Pemakaman Arab Bontoala, kawasan Kota lama dengan fungsi guna lahan sebagai permukiman dan 
perdagangan jasa. Sepanjang koridor terdapat tata informasi tetapi terbatas berupa papan nama jalan, papan reklame took, dan usaha jasa lainnya. Belum adanya penataan pemasangan mengakibatkan koridor ini terkesan tidak teratur, khususnya jika dilihat dari tampilan visual signage yang ada baik secara desain maupun perletakan menyebabkan pencemaran visual. Keberadaan signage di Kelurahan Bontoala Tua terutama main entrance koridor yang menuju ke kawasan Pekuburan Arab kurang mendapat perhatian. Belum ada identitas kawasan Bunga Ejaya, belum adanya papan informasi pada node koridor Jalan Bunga Ejaya dan Jalan Tinumbu yang menandakan akses menuju Pemakaman Arab atau dengan kata lain dari aspek estetika belum adanya signage kawasan yang bernilai arsitektur Islam dan mencirikan eksistensinya sebagai kawasan wisata ziarah Pekuburan Arab/ Sayye'.

Sistem tata informasi dalam urban design disebut signage system berfungsi untuk mempermudah pejalan kaki mengenal fungsi bangunan, penempatannya tidak boleh menghalangi bukaan bangunan dan tidak mengurangi jalur minimum pejalan kaki sebesar 2 meter (Nasruddin \& Marpaung, 2018). Selain itu, perancangan signage dan media interaktif seharusnya sudah terintegrasi branding tempat (Hanifunisa \& Swasty, 2020). Signage menurut Gibson (2009) merupakan objek yang memberikan arahan dan membantu manusia dalam menavigasi ruang atau tempat, arahan dan sarana informasi untuk kenyamanan di lokasi, dan dapat menjadi sarana efektif dalam membangun dan mengembangkan sebuah brand. Ketiadaan sistem penunjuk arah (wayfinding system) terbukti mampu menimbulkan ketidakteraturan dalam penataan ruas jalan kendaraan, pejalan kaki hingga kebutuhan penanda toko dan bangunan fungsional lainnya (Prastomo, 2018). Lebih lanjut dikatakan bahwa konsep visibilitas identitas baik lingkungan terbuka maupun facade bangunan dapat dipertimbangkan dalam ukuran yang mudah dilihat dan dimengerti peziarah, baik oleh peziarah yang menggunakan kendaraan bermotor maupun berjalan kaki. Sistem penanda atau sistem informasi merupakan keharusan suatu tempat untuk mendapatkan informasi yang cepat dan jelas yang dikemas secara menarik dan memberikan nilai tambah dengan strategi memvisualisasikan keunikan kawasan, menyenangkan, diinspirasi dari alam, dan tidak membosankan (Ahmad, 2013).

Perancangan signage untuk perletakan baik secara dua dimensional maupun tiga dimensional perlu mendapatkan perhatian khusus (Wijayanti, 2019). Menurut Puspitasari dan Darmawan (2013), signage tidak sebatas diartikan sebagai tanda, tetapi lebih kepada tema suatu area yang dirancang untuk menginformasikan tempat dan arah baik dalam lingkup interior maupun eksterior. Lebih lanjut dinyatakan juga bahwa setiap sudut pandang atau persepsi dari pengguna jalan dan tanggapannya terhadap keberadaan signage dikondisikan oleh karakteristik khusus manusia, karena faktor manusia memegang peranan penting dalam memperoleh solusi terbaik yang merupakan 'good design solution' bagi masyarakat pengguna.

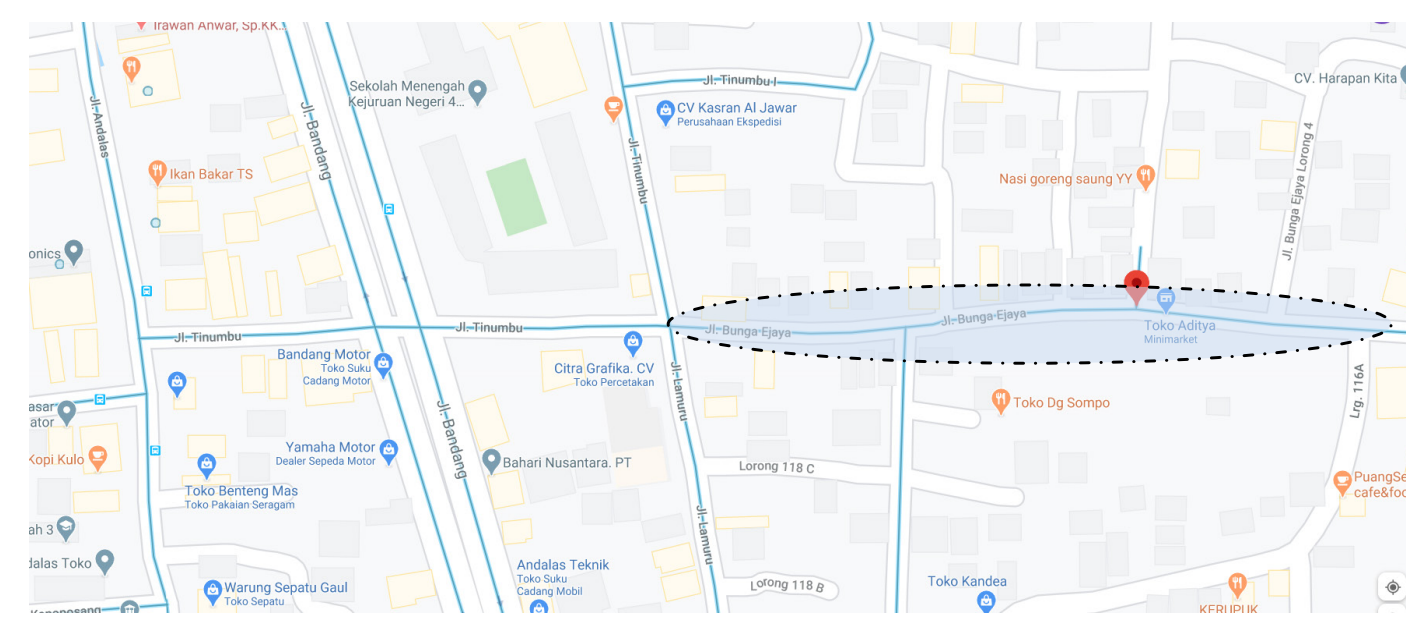

Gambar 1. Peta Lokasi dan Koridor Jalan Bunga Ejaya sebagai Akses Utama ke Area Pekuburan Arab 
Tata informasi atau dengan kata lain sign system merupakan bentuk informasi dan orientasi kota yang dirancang khusus sebagai elemen perkotaan. Dengan demikian, penataan tata informasi sangat diperlukan untuk mencapai keseragaman bentuk, tampilan visual koridor yang menarik dan estetika, serta memudahkan penyampaian informasi bagi para pejalan kaki dan pengemudi kendaraan bermotor. Nasruddin \& Marpaung (2018) menyatakan bahwa agar tidak terjadi kesemrawutan maka diperlukan pengaturan dan penempatan baik dari ukuran, ketinggian, dan luasan seperti papan nama toko tidak lebih dari 15\% luasan dinding, papan reklame hanya boleh diletakkan pada lantai dua, papan iklan layanan masyarakat wajib memiliki izin dari pemerintah setempat, papan nama neon box dengan luas maksimal 1,2 meter persegi dengan ketinggian 2 meter dari atas tanah dan untuk papan reklame bagian sisi panelnya tidak boleh menjorok ke badan jalan.

Dari teori-teori di atas dapat disimpulkan bahwa signage adalah elemen fisik urban design yang berfungsi sebagai navigasi, menginformasikan tempat, arah, dan identitas ruang secara visual.

Di sisi lain, tingginya jumlah peziarah yang datang berkunjung ke Pemakaman Arab Bontoala sebagai salah satu makam tertua yang mengiringi perkembangan agama Islam di Kota Makassar ini juga menjadi pertimbangan perlunya dibuat signage. Dalam wawancara kami kepada juru kunci Pemakaman Arab Bontoala dapat disimpulkan bahwa secara regular, pengunjung harian berjumlah belasan, dan mencapai puluhan jumlah pengunjung khususnya di hari Jumat, weekend, maupun hari libur nasional, serta sebelum memasuki bulan Ramadan. Pada hari-hari besar keagamaan misalnya Hari Raya Idulfitri dan Iduladha, peziarah Pekuburan Arab dapat mencapai jumlah ratusan lintas gender dan usia. Bahkan, mantan Wakil Presiden Republik Indonesia Bapak Muhammad Jusuf Kalla secara periodik datang berziarah ke makam orang tuanya yang berada di kompleks pekuburan ini. Karena pentingnya keberadaan signage maka diperlukan perancangan dan pembuatan signage pada Jalan Bunga Ejaya berupa tanda petunjuk arah Pemakaman Arab Bontoala (lihat Gambar 3). Lokasi perletakannya pada node Jalan Bunga Ejaya dengan Jalan Tinumbu dan Jalan Lamuru yang ditempatkan pada area zona pejalan kaki yang dirancang berbentuk persegi empat (lihat Gambar 2) dimana bentuk persegi empat efektif untuk tanda yang berisi informasi. Pendekatan yang digunakan dalam mendesain signage yaitu pertama disesuaikan dengan kondisi lingkungan sekitar, dipertimbangkan agar menjadi satu kesatuan dengan elemenelemen yang sudah ada, karena suatu signage harus memenuhi aspek fungsional dan estetika. Tujuan kegiatan pengabdian masyarakat ini adalah untuk merancang dan membuat signage yang akan dipasang pada node koridor Jalan Bunga Ejaya. Manfaat kegiatan pengabdian ini adalah terbentuknya struktur visual koridor jalan serta terciptanya citra lingkungan dengan menghidupkan street space dengan adanya signage Pemakaman Arab Bontoala.

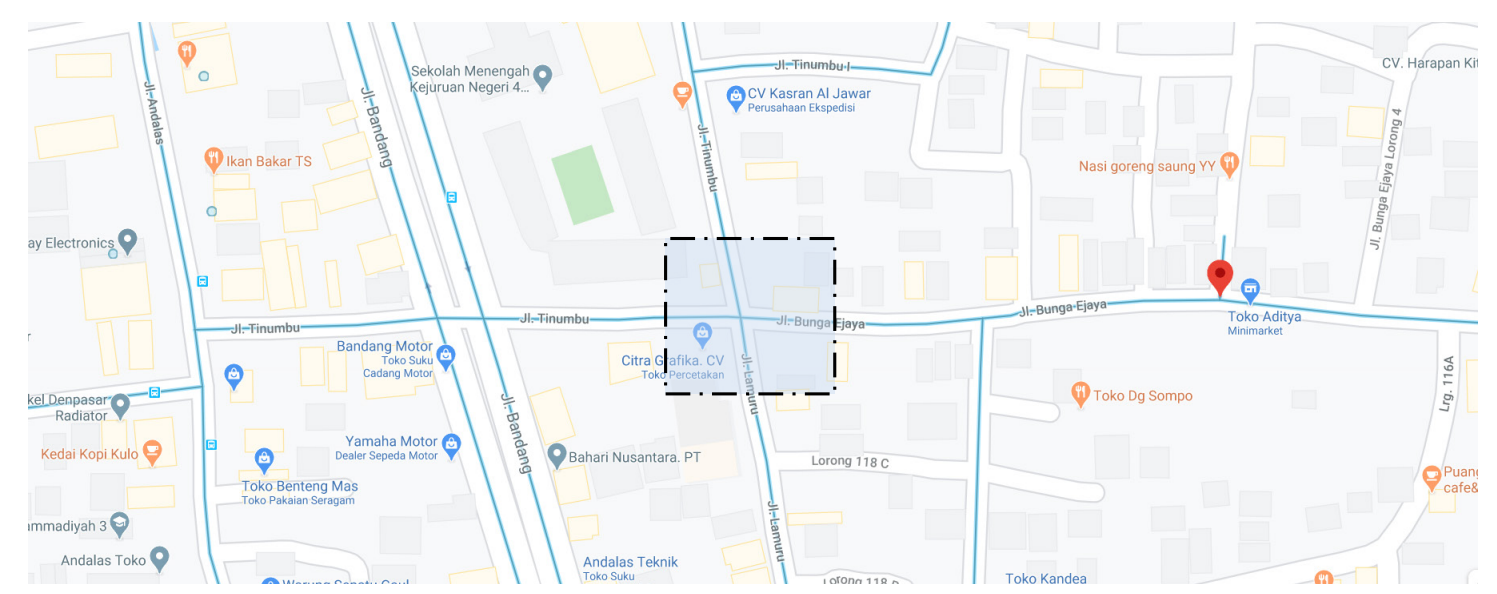

Gambar 2. Node Berbentuk Segi Empat yang Terbentuk dari Pertemuan Jalan Bunga Ejaya, Jalan Lamuru, dan Jalan Tinumbu 

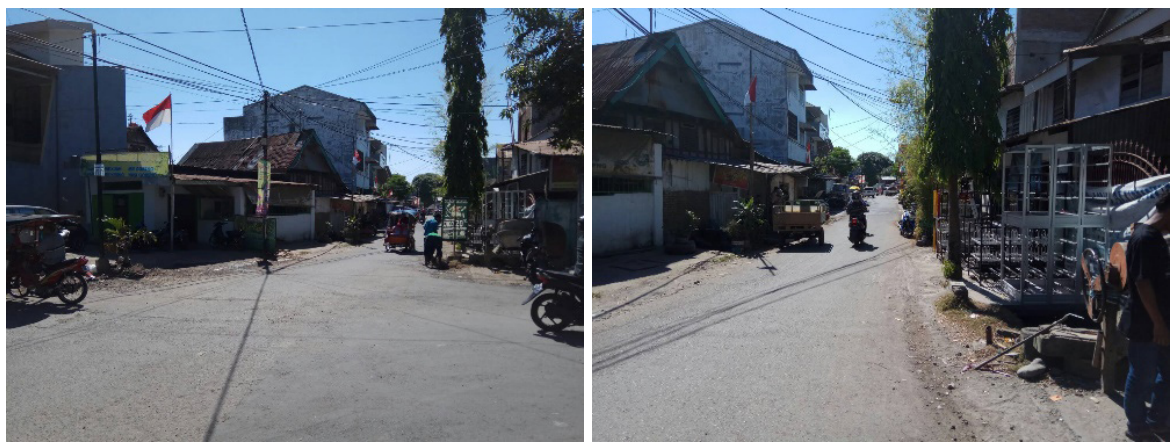

Gambar 3. Belum Terdapat Penunjuk Arah ke Pemakaman Arab Bontoala

Dengan adanya desain signage yang memperhatikan unsur visibilitas (terlihat), legibilitas (terbaca) dan aspek visual (estetika) di koridor Jalan Bunga Ejaya diharapkan dapat berfungsi sebagai informasi petunjuk arah dan menjadi nilai tambah visual koridor sebagai akses utama Pemakaman Arab Bontoala yang memperkuat eksistensinya sebagai Kawasan Wisata Ziarah.

\section{METODE}

Metode yang digunakan dalam kegiatan penataan visual signage ini adalah metode participatory approach (pendekatan semi partisipatif) yaitu dengan melibatkan tokoh kunci seperti tokoh masyarakat yang berpengaruh dan dituakan di sekitar lokasi Pemakaman Arab Bontoala, Ketua RT dan RW, serta masyarakat setempat yang terdiri atas masyarakat yang tinggal di sepanjang koridor Jalan Bunga Ejaya serta masyarakat yang bermukim di sekitar kompleks pemakaman. Hasil dari pendekatan ini menjadi landasan untuk menentukan lokasi spot/titik signage, bentuk desain signage yang akan digunakan yaitu dengan pendekatan nuansa Islami, kegiatan pembuatan dan pemasangan signage.

Pada tahap awal, Tim Pelaksana Pengabdian mengajak tokoh masyarakat menemukenali identitas lingkungannya melalui survei awal yaitu survei bersama tokoh masyarakat di koridor Jalan Bunga Ejaya dan Jalan Tinumbu pada path yang menghubungkan ke Pemakaman Arab Bontoala. Pada tahapan survey tersebut, dibuat sketsa rencana titik peletakan elemen.

Tahap selanjutnya adalah pelaksanaan kegiatan pengabdian meliputi sosialisasi maksud, denganpemaparandaritimpengabdianmengenai tujuan dan metode pelaksanaan kegiatan. Kemudian dilanjutkan dengan pemaparan teori yang berkaitan dengan peran dan fungsi signage, tipologi, serta jenis dan manfaatnya dan seperti apa partisipasi masyarakat dalam pelaksanaan kegiatan. Kemudian peserta juga memaparkan

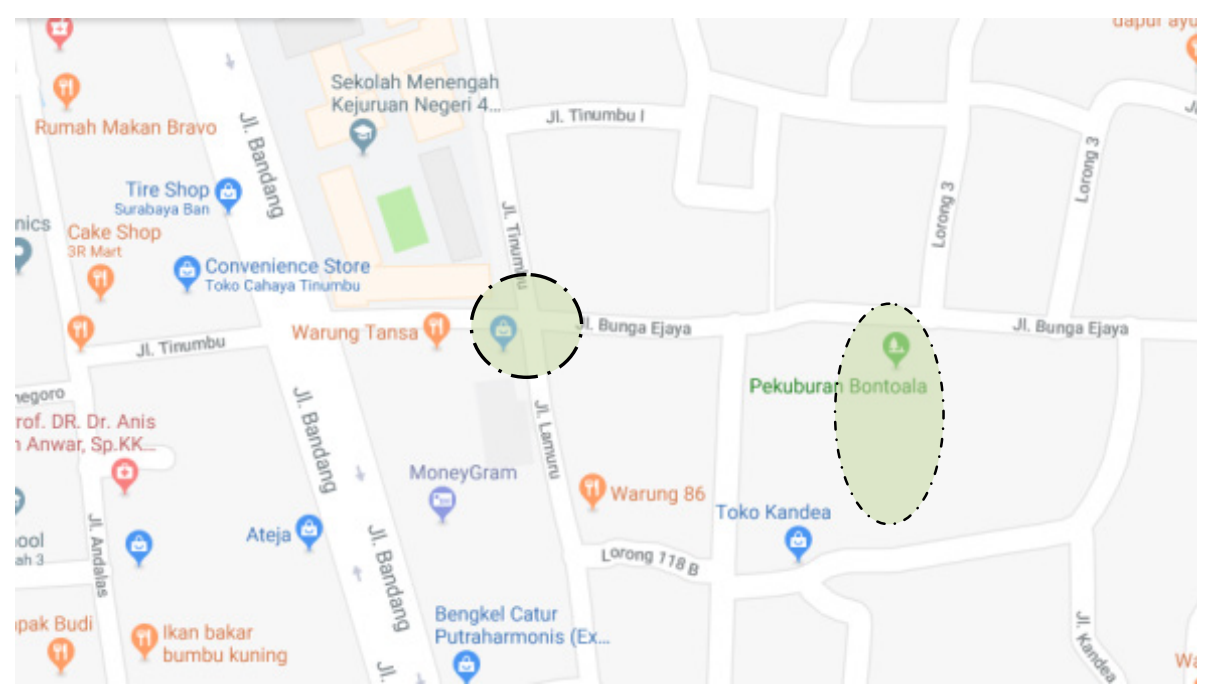

Gambar 4. Titik/Spot Perletakan Signage Berada pada Pangkal Jalan Bunga Ejaya 


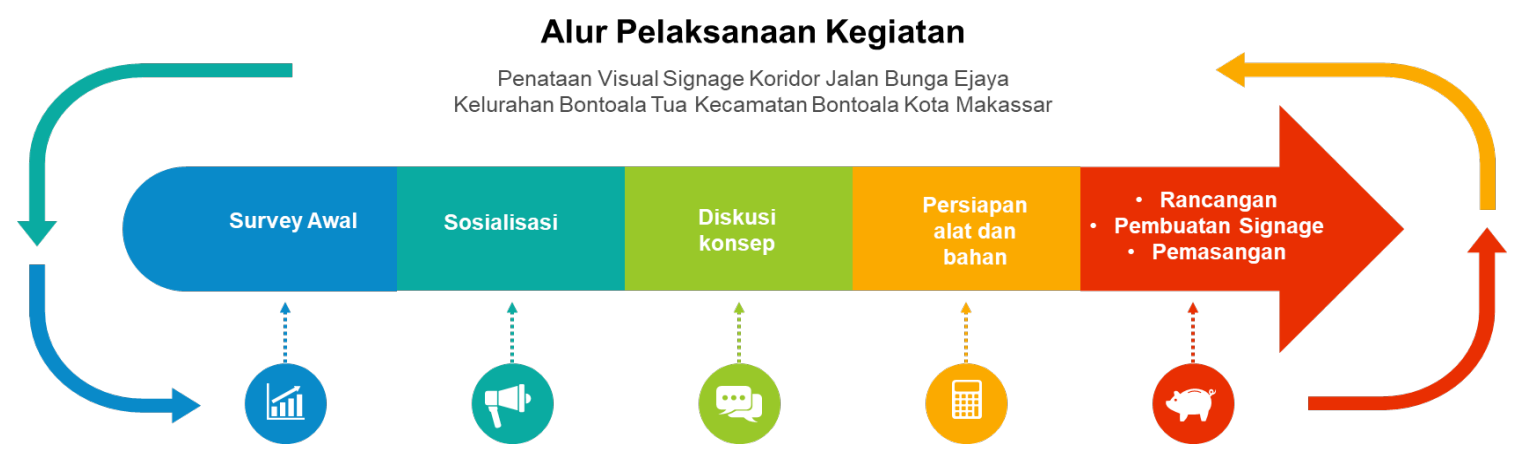

Gambar 5. Diagram Alur Pelaksanaan Kegiatan

permasalahan elemen jalan berdasarkan hasil survei awal. Selanjutnya dilakukan diskusi persiapan untuk tahapan selanjutnya.

Setelah tahap sosialisasi, disusun konsep desain yang nantinya menyepakati rancangan desain signage, termasuk item informasi yang akan tertuang dalam desain signage tersebut. Tahapan ini berlangsung selama dua hari.

Setelah konsep desain selesai, maka tahapan berikutnya adalah pembuatan visual signage pada titik lokasi yang telah disepakati dengan desain signage bernuansa warna hijau dan identik dengan nuansa Islami, bertuliskan arah dan jarak ke Pemakaman Arab Bontoala. Tahapan akhir adalah pemasangan signage, dilakukan bersama-sama dengan masyarakat dan Ketua RT setempat. Prioritas dalam mendesain signage harus menyampaikan pesan komunikatif dan informatif sehingga signage bersifat lebih informatif daripada dekoratif (Situmorang \& Swasty, 2016). Tahapan pembuatan dan pemasangan signage ini berlangsung selama tiga hari.

\section{HASIL DAN PEMBAHASAN}

\section{Tahap Survei Awal}

Tahap survei awal dilakukan bersama beberapa tokoh masyarakat yang ada di sekitar kawasan Pemakaman Arab Bontoala baik Ketua RT, Ketua RW, dan pihak pengelola pemakaman. Survei awal dilakukan dengan menelusuri dan mengidentifikasi elemen fisik pada koridor jalan Bunga Ejaya, Jalan Tinumbu dan Jalan Lamuru. Hasil identifikasi dibuat pada kertas sketsa dan dilengkapi dengan dokumentasi titik-titik perletakan elemen furniture jalan. Survei awal menunjukkan bahwa belum ada elemen furniture jalan berupa apapun yang menjadi penanda sepanjang koridor jalan menuju Pekuburan Arab Bontoala (Gambar 6). Tim Pelaksana Pengabdian memberi masukan agar sebaiknya titik/spot perletakan signage berada pada area yang berbentuk segi empat dengan mempertimbangkan keefektifitasan pembacaaan signage oleh pengguna jalan, serta letaknya yang berada pada akses utama Kawasan Pekuburan Arab.

\section{Tahap Sosialisasi}

Tahap sosialisasi dilakukan dengan pemaparan Ketua Tim Pengabdi kepada peserta mengenai maksud dan tujuan dilakukannya pengabdian masyarakat dari Universitas Muhammadiyah Makassar, serta metode pelaksanaan kegiatan yang akan dilakukan. Selanjutnya pemaparan dilakukan juga oleh anggota tim pengabdian menjelaskan peran dan fungsi signage di koridor jalan, dan partisipasi masyarakat dalam pelaksanaan kegiatan pengabdian. Pada tahap sosialisasi ini dihadiri oleh 15 orang peserta terdiri dari

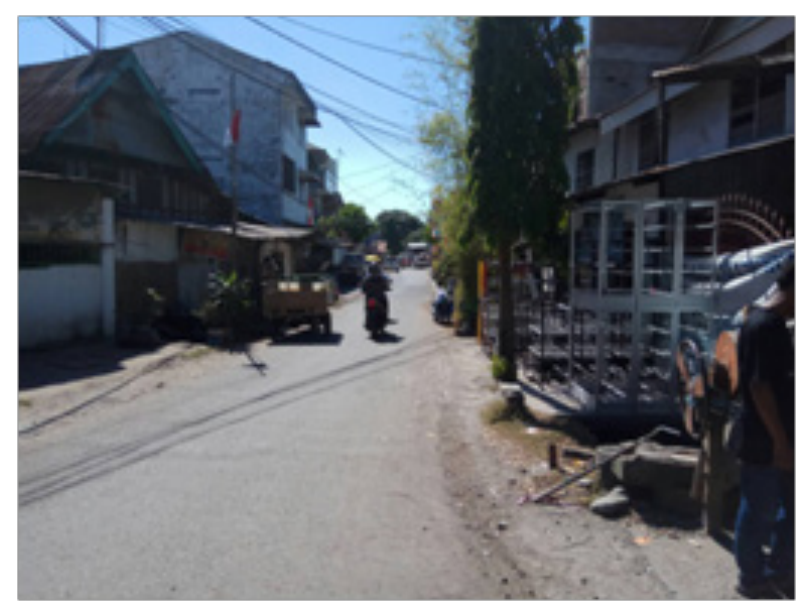

Gambar 6. Survei Awal Kondisi Koridor Jalan Bunga Ejaya 
Ketua RT, Ketua RW, dan warga masyarakat yang bertempat tinggal di Jalan Bunga Ejaya dan sekitar Pemakaman Arab Bontoala. Ketua RT memberikan sambutan kepada peserta dan membahas rangkaian kegiatan yang akan dilakukan dan yang telah dilaksanakan sebelumnya pada tahapan survei awal.

Pada sosialisasi ini Tim Pengabdian memberikan penjelasan kepada peserta tipologi signage dan jenis-jenisnya serta manfaatnya terhadap lingkungan. Pada tahap sosialisasi tersebut Ketua RT menyampaikan juga beberapa permasalahan elemen pada koridor Jalan Bunga Ejaya, Jalan Tinumbu, dan Jalan Lamuru. Kemudian dilakukan juga diskusi tahapan selanjutnya dan langkahlangkah persiapan. Hasil diskusi disepakati lokasi pemasangan signage yaitu berada di node antara Jalan Tinumbu, Lamuru, dan Bunga Ejaya yang merupakan koridor utama menuju PemakamanArab/Sayye'. Pertimbangan peserta perletakan pada node jalan karena merupakan simpul strategis di mana aktivitas saling bertemu dan titik pergerakan ke segala arah, sehingga dapat terlihat dari beberapa arah jalan. Selain itu bila signage ditempatkan pada node jalan, maka pengamat yang melalui jalan tersebut bisa merasakan masuk ke distrik Pemakaman Arab Bontoala. Posisi penempatan signage di ujung Jalan Bunga Ejaya yang berorientasi ke Jalan Bunga Lamuru dan Jalan Tinumbu.

\section{Tahap Penyusunan Konsep Desain}

Konsep penataan signage sebagai decision point perlu memperhatikan sudut pandang user secara vertikal, penggunaannya sign hybrid harus dihindari lebih menggunakan sign jenis grafis untuk efektivitas pemberian informasi pada pengujung sesuai kebutuhan (Taufiq \& Wulandari, 2016).

Tahap penyusunan konsep desain melalui metode participatory approach (pendekatan partisipatif) dengan melakukan diskusi dengan tokoh masyarakat untuk menentukan desain visual signage yang sesuai dengan identitas lingkungan. Metode ini digunakan karena tokoh masyarakat dianggap sebagai salah satu pengguna jalan dan berdomisili di lokasi, di mana setiap sudut pandang atau persepsi dari pengguna jalan dan tanggapannya terhadap signage dikondisikan oleh karakteristik khusus manusia, baik secara biophysics-pshyche, socioculture, spiritual cosmologis transcendental dengan kelima inderanya (Puspitasari \& Darmawan, 2013). Lebih lanjut dikatakan bahwa faktor manusia sebagai pengguna memegang peranan penting dalam memperoleh solusi terbaik yang merupakan 'good solution' bagi masyarakat pengguna signage tersebut.

Penyusunan konsep diawali dengan pemaparan signage dari sisi historis, penggalian tema yang konsisten dan sesuai dengan tempat yang akan dibuatkan signage informasinya, tujuan pembuatannya, penggunaannya, standar grafis, material, dan penempatannya. Dalam pemaparan tersebut dijabarkan bahwa awalnya sejarah signage bermula dari banyak desainer wayfinding yang merupakan orangorang kelahiran masa perang dunia II, dimana mereka mengalami kondisi politik, lingkungan,

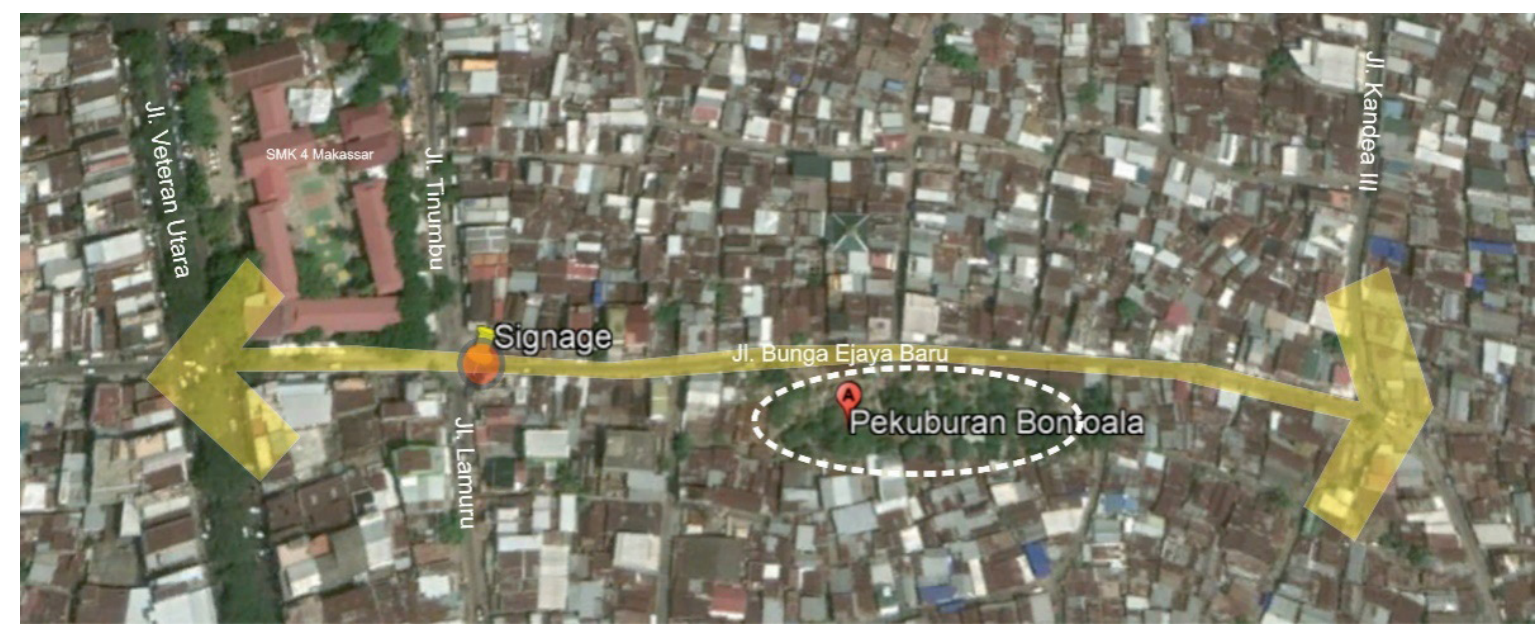

Gambar 7. Signage pada Node Menjadi Identitas Baru pada Simpul Koridor 
serta sosial seperti Vietnam dan permasalahan lainnya pada tahun 1970an. Hal tersebut dimotivasi oleh rasa senasib dan kreativitas secara bertahap mereka membawa wayfinding ke abad 21 berdasarkan pengalaman desainer yang ada pada periode sebelumnya. Pada masa perang dingin 1960, para kritikus, pelajar, dan desainer merasa bahwa pertumbuhan kota yang semakin kompleks membutuhkan sebuah perancangan penunjuk arah. Ilmu ini kemudian disebut dengan desain signage atau sign system, environmental graphic design dan wayfinding. Seiring berjalannya waktu, beberapa individu dan perusahaan mulai fokus dalam mengembangkan dan merancang signage.

Selanjutnya dilakukan diskusi dengan membuat sketsa beberapa contoh alternatif desain signage yang dapat dipilih oleh masyarakat setempat. Alternatif desain mencakup bentukbentuk geometris serta pemilihan warna yang memungkinkan (Gambar 9 dan 10). Mengingat beberapa warna tidak dapat dipilih karena serupa dengan rambu-rambu lalu lintas misalnya warna kuning, warna putih, atau warna biru. Diskusi tersebut menghasilkan keputusan untuk membuat signage yang bernuansa Islami. Nuansa Islami ditonjolkan pada tampilan visual warna menggunakan hijau sebagai simbol keislaman sehingga sesuai dengan image sebagai elemen petunjuk arah menuju ke Kawasan Pemakaman Islam Bontoala. Bentuk signage menggunakan bentuk geometri persegi panjang, memberi kesan sederhana, mudah diingat, dan terkesan ringan. Hal ini sesuai dengan Pernyataan Wijayanti (2019) bahwa desain signage perlu memperhatikan standar pemilihan warna sesuai dengan peraturan namun juga tetap dapat diinovasi guna menambah citra kota. Signage yang dibuat merupakan directional sign yang digunakan untuk penunjuk arah lokasi yang akan dituju pengunjung.

Menurut Surya (2016) secara umum tandatanda dapat diklasifikasikan sesuai dengan fungsi diantaranya (1) Informasi seperti peta, direktori atau tanda-tanda instruksional, (2) Arah seperti lokasi layanan, fasilitas, ruang fungsional, seperti posting tanda atau arah panah, (3) Identifikasi seperti nomor kamar, tanda toilet dan sebutan lantai, dan (4) Keselamatan dan peraturan, seperti tanda peringatan, rambu lalu lintas, tanda keluar, tanda tanda menyampaikan aturan, dan peraturan. Jenis signage yang digunakan pada lokasi adalah free-standing sign karena penempatannya digunakan untuk koridor jalan (outdoor). Dengan konsep demikian diharapkan menjadi salah satu upaya untuk membangun identitas visual yang dapat menciptakan karakteristik khas yang kuat pada kawasan dan mampu meningkatkan awareness pada pengunjung apalagi bila ditempatkan sesuai standarisasi sehingga mudah menemukan lokasi yang dituju (Maymun \& Swasty, 2018).

Tim Pelaksana Pengabdian memberikan dua alternatif desain signage (Gambar 9 dan Gambar 10) yang paling sesuai dengan kriteriakriteria yang disebutkan sebelumnya antara lain nuansa Islami, warna yang berbeda dari rambu-rambu lalu lintas, dan bentuk geometris sederhana, mudah diingat, dan terkesan ringan.
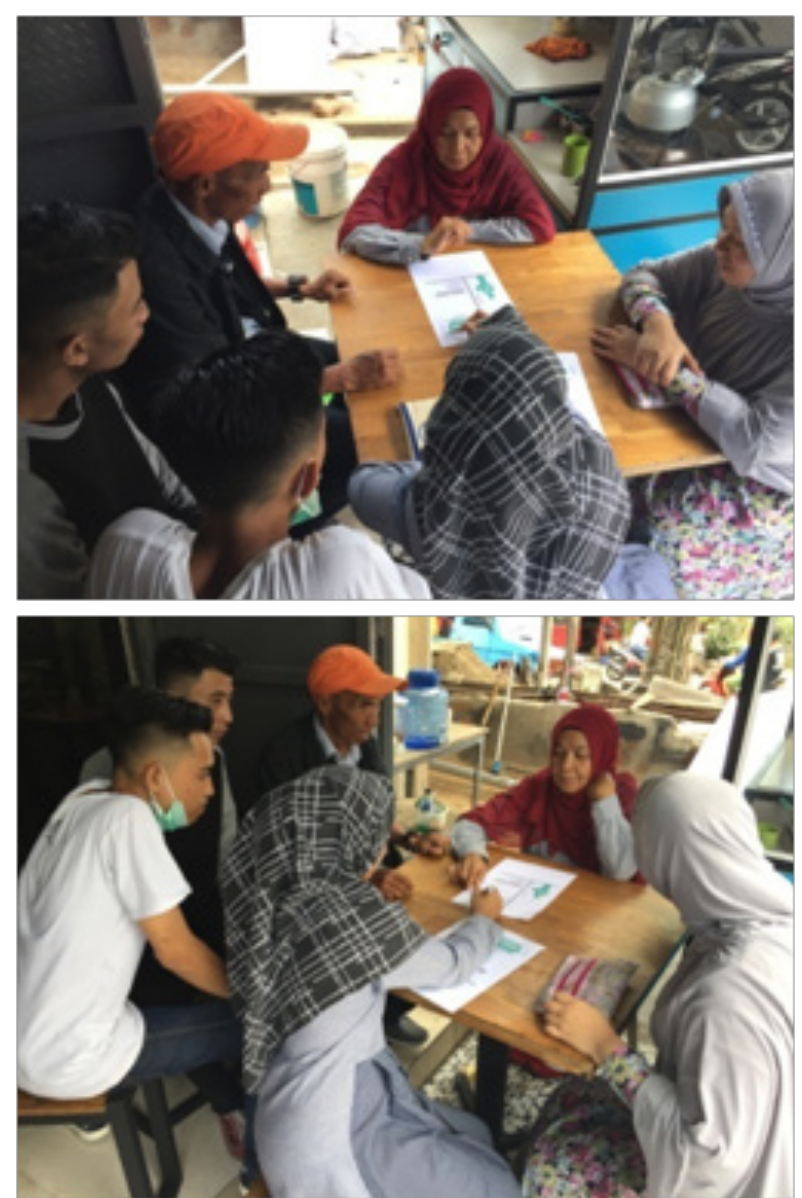

Gambar 8. Diskusi Konsep Desain Signage 


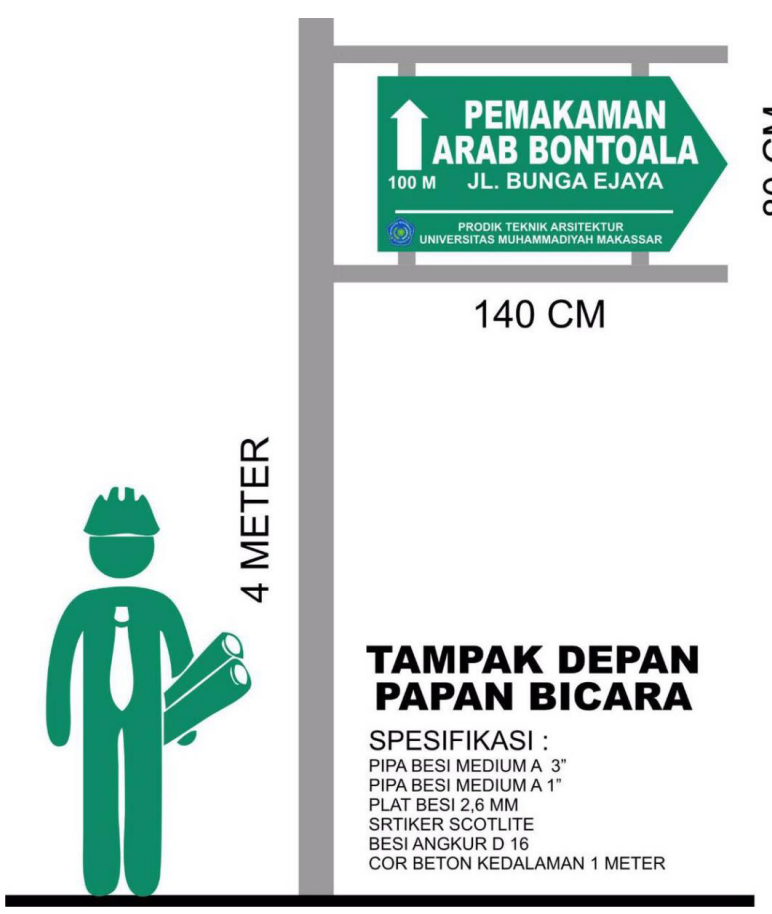

Gambar 9. Design Signage Alternatif 1

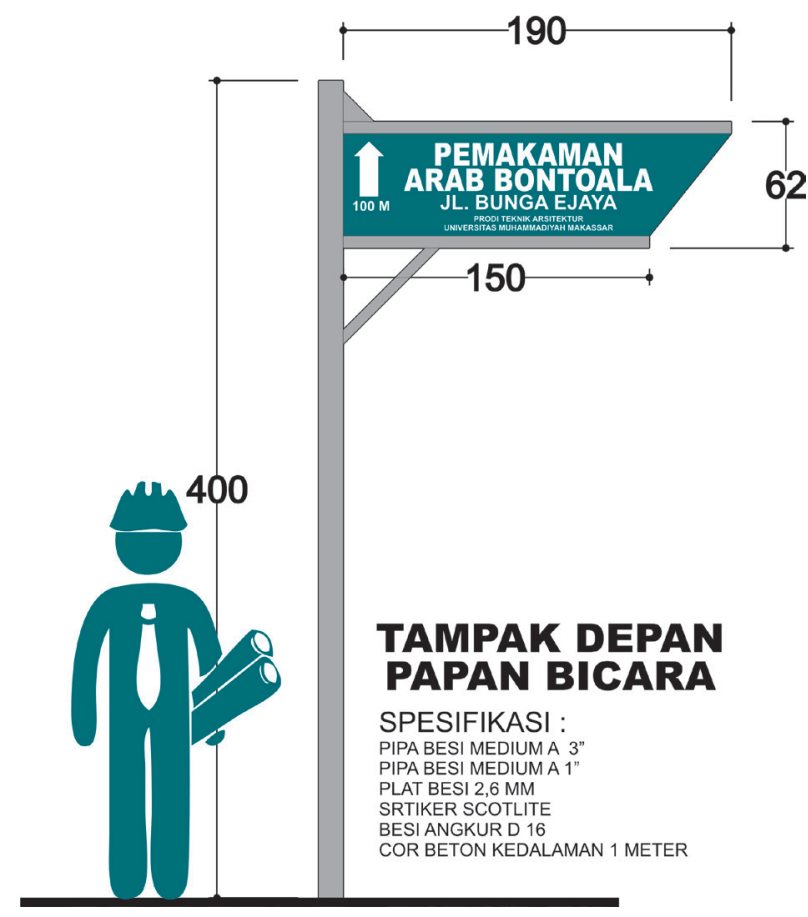

Gambar 10. Desain Signage Alternatif 2

Dari kedua alternatif desain signage yang diberikan oleh tim pelaksana pengabdian, lalu diadakan diskusi mengenai alternatif desain mana yang akan digunakan. Hasil diskusi disekapakati bahwa desain signage yang terpilih adalah desain signage alternatif 2 dengan pertimbangan bahwa desain ini terlihat
Tabel 1. Konsep Visual Desain Signage

\begin{tabular}{lll}
\hline \multicolumn{1}{c}{ Konsep } & \multicolumn{2}{c}{ Keterangan } \\
\hline Tema & Nuansa Islami & \\
\hline Bentuk & $\begin{array}{l}\text { Perpaduan segitiga dan persegi } \\
\text { panjang (panah penunjuk arah) }\end{array}$ \\
\hline Tipografi & $\begin{array}{l}\text { Tipografi yang digunakan } \\
\text { adalah jenis dekoratif , terdapat }\end{array}$ \\
& $\begin{array}{l}\text { logo kampus Universitas } \\
\text { Muhammadiyah dan penunjuk } \\
\end{array}$ & \\
\hline Warna & Hijau (papan signage) & kombinasi \\
& abu-abu (tiang) \\
\hline Material & Plat besi, pipa besi \\
\hline
\end{tabular}

lebih simpel, praktis, ringan, dan sekaligus kuat karena papan informasi tulisan langsung menyatu dengan tiang besi penopangnya. Berbeda dengan desain signage alternatif 1 yang menurut mereka mudah dilepas oleh orang yang tidak bertanggung jawab (rawan vandalism).

Konsep visual yang akan diimplementasikan pada desain signage Pemakaman Arab Bontoala memperhatikan aspek warna, tipografi, material dan jenis pemasangan yang dijabarkan dalam tabel 1.

\section{Persiapan Alat dan Bahan}

Tenaga kerja terdiri atas beberapa tukang dan masyarakat setempat. Alat-alat yang digunakan terdiri atas meteran, kabel stop kontak, gurinda, travo las, kawat las, batu pemotong besi, batu penghalus besi, kertas gosok, sekop, linggis, dan kuas cat berdiameter 2 inch. Bahan-bahan yang digunakan terdiri atas pipa besi berdiameter 1 dan 3 inch, plat besi 2.6 $\mathrm{mm}$, besi beton diameter $16 \mathrm{~cm}$, semen, pasir, batu kerikil,air bersih, wadah untuk mencampur, bambu untuk menopang, cat dasar, cat besi warna abu silver, cat besi warna hijau, dan sticker scotlite. Cat besi yang dipilih harus mengandung anti karat dan tahan panas. Pekerja terdiri atas kepala tukang, tukang las, dan buruh.

Beberapa material yang dapat digunakan dalam merancang signage diantaranya adalah metal, kaca, kayu, batu, banner, plastik, dan composite. Masing-masing memiliki pertimbangan dalam proses pengerjaan dan pemeliharaanya. Material metal terdiri dari 
aluminium, stainless steel, perunggu, dan kuningan digunakan secara umum dalam pembuatan signage, karena mudah dibentuk dan tahan lama. Kaca sering diaplikasikan untuk interior dan eksterior, karena bagian belakang dapat ditambahkan aksesoris lampu baik pada kacajenislaminated, tempered, fritted, borosilikat, float, maupun low emissitivity. Material kayu dibanding material lainnya kurang tahan lama terutama untuk lokasi dengan curah hujan tinggi dan dapat menua seiring berjalannya waktu. Batu dapat digunakan sebagai bagian atau dasar signage, memberikan kesan menyatu pada suatu latar belakang atau arsitektur dengan proses carving, sandblasting atau water-jet cutting. Jenis batu yang diaplikasikan bisa berupa slate, sandstone, marmer, batu kapur, maupun granit. Banner dapat digunakan untuk pameran temporer atau outdoor signage terbuat dari kain, plastik, atau material lentur lainnya. Banner dapat berupa vinyl, nilon, tyvek, poplin, dan dakron. Selain itu material lain untuk signage plastik yang dapat dicetak atau disablon, serta material composite yang permukaannya dapat dicat, dicetak ataupun langsung digunakan.

\section{Tahap Perakitan dan Pemasangan Signage}

Pertama-tama dilakukan pengukuran pipa besi dan plat besi agar sesuai dengan desain signage yang direncanakan oleh tukang las secara mandiri. Setelah diukur, pipa besi serta plat besi tersebut dipotong dengan menggunakan gurinda sesuai ukuran dari spesifikasi desain. Hasil potongan pipa besi dan plat besi kemudian dirangkai menjadi satu kesatuan utuh dengan menggunakan teknik las. Setelah dilakukan pengelasan, lalu dihaluskan dengan menggunakan kertas gosok (Gambar 11). Selanjutnya, rangkaian signage tersebut dicat menggunakan cat dasar. Setelah kering, dicat menggunakan cat besi warna abu-silver, dan dilakukan pengecekan ulang kesesuaian ukuran tiang signage dengan desain (Gambar 12). Hasil signage tampak bagian penempatan tulisan informasi dicat warna hijau (Gambar 13) dan akan dipasangkan sticker scotlite yang berisi keterangan atau informasi yang ditampilkan oleh signage.

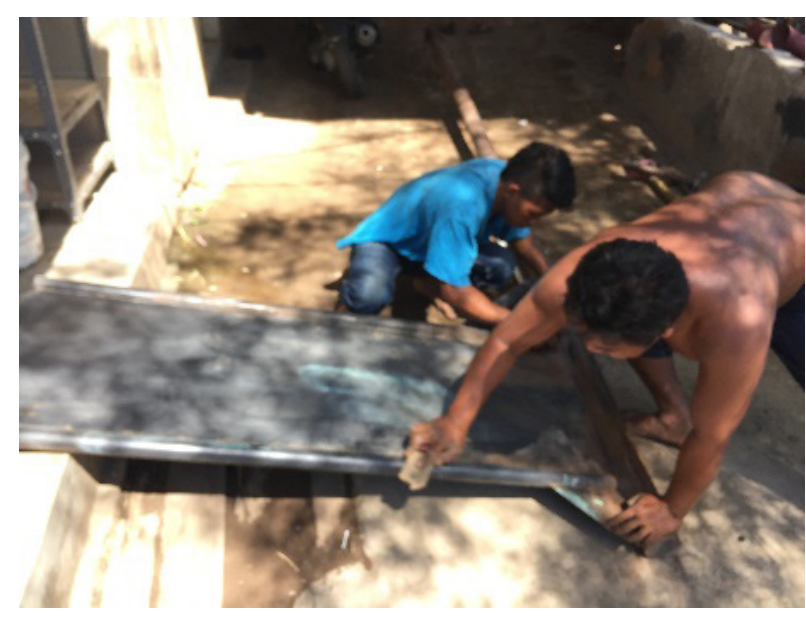

Gambar 11. Tahap Penghalusan Papan Signage

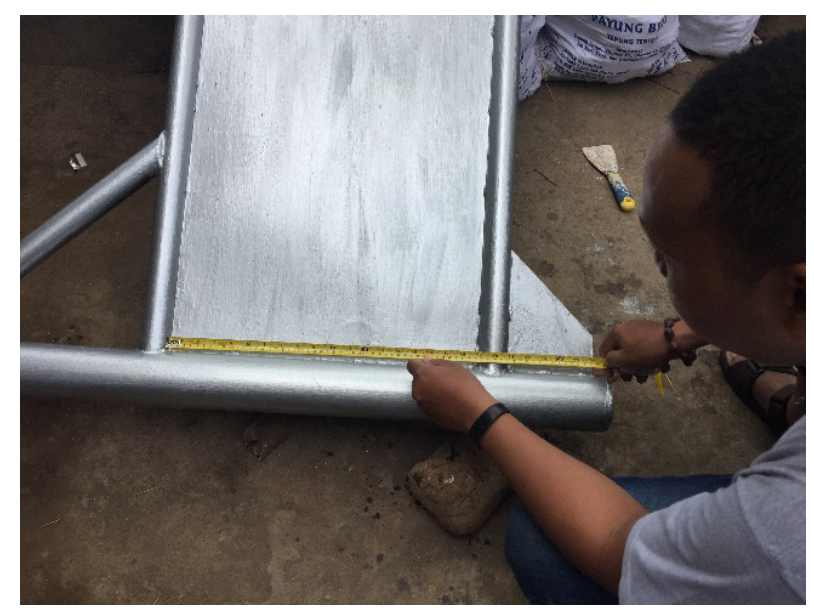

Gambar 12. Tahap Pengecekan Ukuran

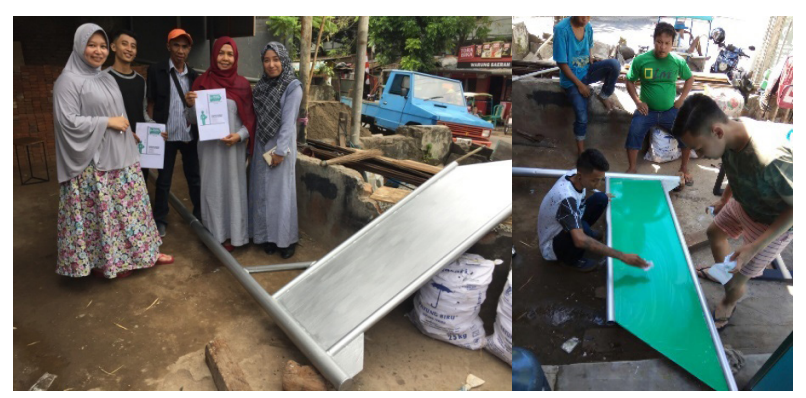

Gambar 13. Tahap Pemasangan Sticker Scotlight

Tahap pemasangan serta finishing visual satu buah signage dengan ukuran dan spesifikasi sesuai desain signage alternatif 2 (Gambar 10) dilakukan secara bersama-sama antara tim pelaksana pengabdian dengan masyarakat setempat dan Ketua RT. Pada tahap pemasangan, juga memperhatikan ketinggian signage dan arah datang cahaya juga layout. Sesuai kesepakatan sebelumnya, signage dipasang di node Jalan Bunga Ejaya, Jalan Tinumbu, dan 
Jalan Lamuru, dengan harapan agar signage dapat terbaca dengan jelas dan mudah dipahami masyarakat. Ketinggian dimensi perletakan signage yang sesuai dengan segala keadaan kondisi pengunjung, baik pengunjung yang memiliki keterbatasan seperti memakai kursi roda, keterbatasan dalam melihat terutama manula (Ruki \& Nediari, 2014).

Tahap pemasangan signage diawali dengan penggalian tanah menggunakan sekop dan linggis pada titik yang telah ditentukan dengan kedalaman kurang lebih 1 meter, serta disiapkan juga pencampuran bahan beton menggunakan semen, pasir, dan batu kerikil dengan perbandingan 1:2:3 serta besi beton diameter $16 \mathrm{~cm}$. Selanjutnya tiang signage dimasukkan ke dalam lubang hasil galian yang tersedia dan dalam posisi berdiri dengan bantuan bambu penopang, serta dituangkan bahan campuran adukan beton yang telah disiapkan sebelumnya. Tiang bambu penopang tetap digunakan sampai campuran adukan beton kering dan mengeras, hingga signage dapat dilepas berdiri sendiri.

\section{Monitoring dan Evaluasi}

Setelah seluruh kegiatan selesai, tim pelaksana pengabdian melakukan monitoring dan evaluasi secara sederhana terhadap signage yang telah terpasang. Untuk mengamati kondisi fisik signage serta perilaku masyarakat setempat dengan kehadiran signage tersebut, serta mengevaluasi peranan dan bentuk desain signage yang dapat menjadi masukan maupun perbaikan bagi perencanaan di kemudian hari. Pengamatan kondisi fisik meliputi keutuhan rangkaian signage yang bebas dari aksi vandalism maupun anarkisme. Pengamatan perilaku masyarakat setempat terkait fungsi signage dalam kehidupan sehari-hari masyarakat sekitar.

Hasil dari monitoring dan evaluasi ini memperlihatkan bahwa koridor Jalan Bunga Ejaya sebelum kegiatan PKM ini, belum terdapat elemen penanda menuju Pemakaman Arab Bontoala. Setelah kegiatan PKM tampak terlihat perubahan dengan adanya signage yang terpasang masih dalam keadaan utuh dan terawat hingga saat ini, walaupun telah mencapai
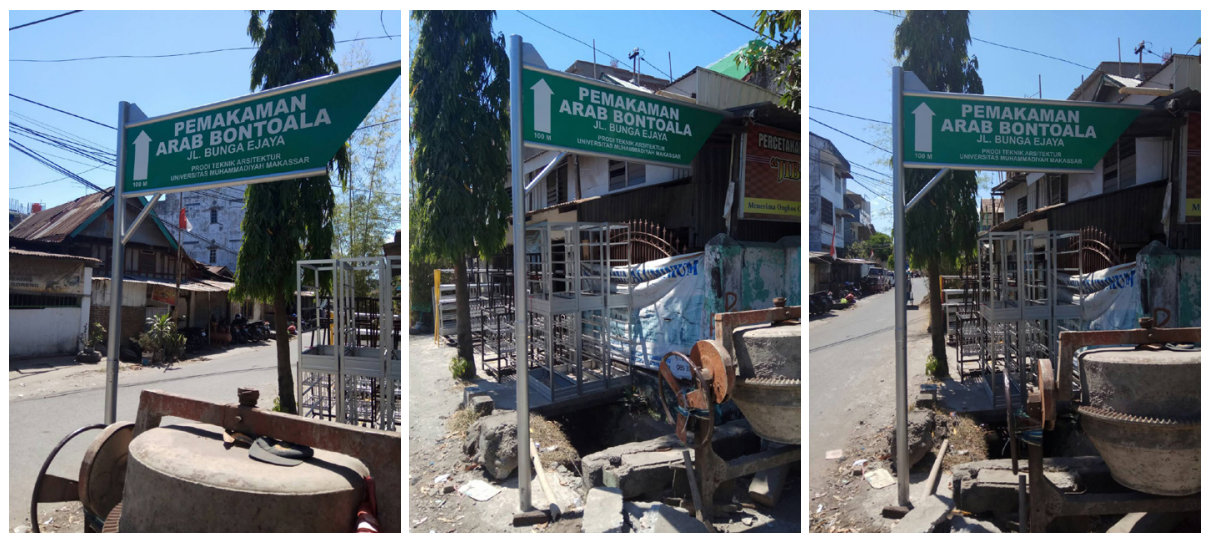

Gambar 14. Tahap Pemasangan Signage
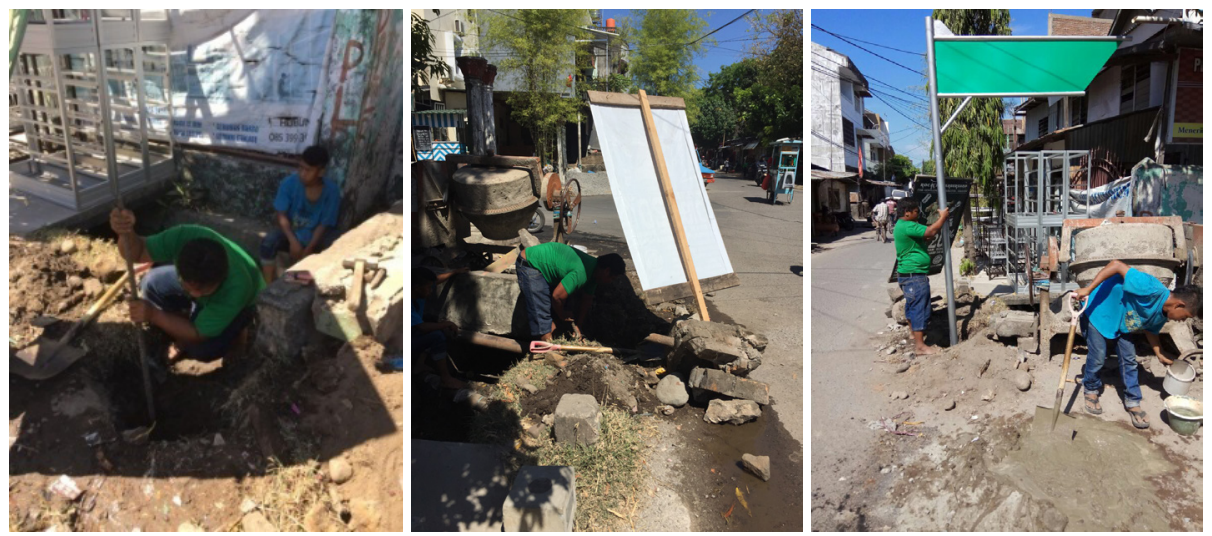

Gambar 15. Signage Telah Terpasang pada Node 
usia tiga tahun. Keberadaan signage tidak hanya berfungsi sebagai penanda teritorial wilayah Pemakaman Arab Bontoala, tetapi juga berfungsi untuk menentukan titik lokasi bagi jasa layanan pengantaran baik ekspedisi maupun aplikasi driver online, sehingga semakin memudahkan masyarakat dalam menggunakan kedua layanan tersebut. Kedepannya diharapkan bahwa bentuk desain signage masih dapat dikembangkan lebih lanjut, misalnya menambah titik jumlah pemasangan dan ragam jenis informasi yang tertuang dalam signage agar menjadi satu kesatuan sebagai penanda wilayah yang lebih luas, atau pemasangan map direction.

\section{SIMPULAN}

Penataan yang dilakukan merupakan bentuk pengabdian masyarakat sebagai wujud Tri Dharma Perguruan Tinggi dalam hal pembuatan directional sign ini merupakan salah satu papan informasi yang membantu pengunjung atau pengguna jalan yang akan berkunjung ke Pemakaman Arab Bontoala. Selain itu, signage ini diharapkan dapat menjadi sarana efektif yang mengarahkan pengunjung menuju ke lokasi tersebut. Hasil monitoring menunjukkan bahwa signage yang telah dibuat juga menjadi identitas lokasi yang dapat membantu driver online untuk menemukan tempat lebih cepat dan mudah di sekitar lokasi tersebut. Adapun saran dari kegiatan pengabdian ini yaitu penataan visual signage dapat dilakukan dengan menghubungkan beberapa visual signage melalui axis atau sumbu-sumbu. Selain itu, pada kawasan masih diperlukan adanya Map Direction yang penempatannya dapat berdampingan dengan signage yang telah dibuat.

\section{UCAPAN TERIMA KASIH}

Tim Pelaksana Pengabdian mengucapkan terima kasih kepada Lembaga Penelitian Pengembangan dan Pengabdian (LP3M) Universitas Muhammadiyah Makassar atas bantuan pendanaan berdasarkan Surat Penugasan Pengabdian kepada Masyarakat N o. 0109 / KO N T R - P E N L / P E N G A B D / VIII/1438/2017 dalam rangka pelaksanaan Program Pengabdian kepada Masyarakat Tahun Anggaran 2017.

\section{DAFTAR PUSTAKA}

Ahmad, A. (2013). Studi Perancangan Identitas Visual Wilayah Karimunjawa. Jurnal Humaniora, 4(1), 567-579.

Hanifunisa, A., Swasty, W. (2020). Signage Informatif dan Interaktif pada The Heritage Palace Kota Surakarta Jawa Tengah. Jurnal Bahasa Rupa, 3(2), 95-103.

Maymun, A.Z., Swasty, W. (2018). Identitas Visual dan Penerapannya pada Signage untuk Kawasan Wisata Edukasi. Serat Rupa Journal of Design, 2(1), 1-13.

Nasruddin \& Marpaung, B.O.Y. (2018). Penataan Tata Informasi sebagai Penanda Visual Kawasan di Koridor Jamin Ginting Pancur Batu. Jurnal Arsitektur dan PerKotaan “KORIDOR”, 9(1), 99-105.

Puspitasari, D.G., \& Darmawan, J. (2013). Signage dan Penerapannya: Lingkungan Jalan Raya Tol Bintaro. Jurnal Humaniora, 4(1), 475-490.

Prastomo, Dicky. (2018). Wayfinding sebagai Solusi Petunjuk Arah di Zona Wisata Ziarah Desa Gunung Pring Muntilan. Jurnal TESA, XIII(1), 55-68.

Ruki, U.A., Nediari, A. (2014). Penerapan Tipografi dalam Sistem Signage pada Interior Ruang Publik. Jurnal Humaniora, 5(2), 822-832.

Situmorang, R.S., Swasty, W. (2016). Signage and Wayfinding Design of DR.H. Kumpulan Pane Regional General Hospital in Tebing Tinggi North Sumatra. Journal of Vicual Communication Design, 1(1), 52-69. 
Surya, G.G. (2016). Perancangan Map Direction dan Signage di Pulau Untung Jawa Guna Memfasilitasi Wisatawan. Jurnal Abdimas, 3(1), 105-122.

Taufiq, S.A., \& Wulandari, R. (2016). Efektivitas Lokasi Penempatan Papan Petunjuk (Signage System) pada Lobby Stasiun Kereta Api Bandung. Jurnal IDEALOG, 1(1), 49-62.

Wijayanti, E.N. (2019). Kajian Tipologi Perletakan dan Desain Signage sebagai Kebutuhan Kota Pelajar dan Wisata (Studi Kasus: Kecamatan Gondokusuman dan Jetis Kota Yogyakarta). 3 Arsitektur dan Keseharian: Keterampilan Lokal, Teknologi Konstruksi, Tektonika dan Pengalaman Meruan, 216-225.

Zubair, M. (2011). Makna dan Fungsi Inskripsi pada Makam Lajangiru di Bontoala Makassar (Studi Arkeo-epigrafi). Jurnal Al Qalam, 17(1), 59-70. 